FIU Law Review

Spring 2015

\title{
Banning the Box: Restricting the Use of Criminal Background Checks in Employment Decisions in Spite of Employers' Prerogatives
}

Ingrid Cepero

Florida International University College of Law

Follow this and additional works at: https://ecollections.law.fiu.edu/lawreview

Part of the Other Law Commons

Online ISSN: 2643-7759

Recommended Citation

Ingrid Cepero, Banning the Box: Restricting the Use of Criminal Background Checks in Employment Decisions in Spite of Employers' Prerogatives, 10 FIU L. Rev. 729 (2015).

DOI: https://dx.doi.org/10.25148/lawrev.10.2.20

This Comment is brought to you for free and open access by eCollections. It has been accepted for inclusion in FIU Law Review by an authorized editor of eCollections. For more information, please contact lisdavis@fiu.edu. 


\section{Banning the Box: Restricting the Use of Criminal Background Checks in Employment Decisions in Spite of Employers' Prerogatives}

Ingrid Cepero*

"People don't realize that all you want to do is have a normal life, and then there's the box you have to check on a job application.",1

— Jamie Scott, convicted felon.

\section{INTRODUCTION}

Yolanda Quesada devoted her career at Wells Fargo as a customer service representative. ${ }^{2}$ She was awarded multiple "recognition awards, service excellence pins, certificates of appreciation," and was even honored for her five-year anniversary with the company. ${ }^{3}$ Despite Yolanda's hard work and dedication, she was suddenly fired-because of a forty-year-old criminal conviction. ${ }^{4}$ Yolanda was convicted of shoplifting clothing in 1972 when she was merely eighteen years old. ${ }^{5}$ At the time, Yolanda was one of twelve children in her family, when "money was tight," and she had nothing to wear to work. ${ }^{6}$ Yolanda made the wrong decision to shoplift, and she paid the consequences both in 1972 and four decades later in 2012 . $^{7}$

* Florida International University College of Law, J.D. May 2015; Georgetown University, B.A. 2012. I would like to thank David Legrand for giving me the inspiration to write this Comment, Fernella Peters for allowing me to learn from her, Ozzie Black for giving me the opportunity to be his intern, and everyone at the U.S. EEOC Miami office that made my learning experience possible. I also want to thank Professor Kerri L. Stone for her guidance and advice, Daniel K. Cartwright for his insightful feedback and for believing in my Comment, and my parents for their unconditional love and support.

1 Cheryl G. Swanson et al., Reentry and Employment: Employers' Willingness to Hire Formerly Convicted Felons in Northwest Florida, in OFFENDER REENTRY: RETHINKING CRIMINOLOGY AND CRIMINAL JUSTICE 203, 203 (Matthew S. Crow \& John Ortiz Smykla eds., 2013).

2 Susanna Kim, Wells Fargo Worker Fired for 40-Year-Old Shoplifting Charge, ABC NEWS (May 8, 2012, 11:34 AM), http://abcnews.go.com/blogs/business/2012/05/wells-fargo-worker-fired-for40-year-old-shoplifting-charge/.

3 Jim Stingl, Will Your Employer Dig Up Your Arrest 40 Years Ago?, MiLwaukeE J. SentineL (May 5, 2012), http://www.jsonline.com/news/milwaukee/will-your-employer-dig-up-your-arrest-40years-ago-0059578-150316185.html.

$\begin{array}{ll}4 & I d . \\ 5 & I d . \\ 6 & I d . \\ 7 & \text { See id. }\end{array}$


Millions of Americans like Yolanda are affected by their criminal pasts. ${ }^{8}$ Minorities, who are already subject to discrimination in the workplace, feel the impact of having a criminal background more harshly than others when seeking employment. ${ }^{9}$ Consequently, the United States Equal Employment Opportunity Commission (EEOC) has stepped in in an attempt to remedy the disparate impact employers' blanket criminal background check policies have on minorities. ${ }^{10}$

Since its establishment, the mission of the EEOC has been to enforce the federal laws that make employment discrimination based on a person's "race, color, religion, sex (including pregnancy), national origin, age (40 or older), disability or genetic information," illegal. ${ }^{11}$ The EEOC not only enforces laws against disparate treatment, but also against disparate impact. ${ }^{12}$ The Supreme Court has defined disparate impact as "employment practices that are facially neutral in their treatment of different groups but that in fact fall more harshly on one group than another and cannot be justified by business necessity." 13

Most recently, in its latest quest to combat disparate impact, the EEOC has focused on companies that enforce blanket criminal background policies as a method of screening applicants and current employees. ${ }^{14}$ These blanket criminal background check policies prevent an applicant from gaining employment if he or she possesses a criminal background. ${ }^{15}$ These policies, and the employers who enforce them, do not take into account whether the offense is related to "the nature of the job," how long ago the

8 Amy L. Solomon, In Search of a Job: Criminal Records as Barriers to Employment, 270 NAT'L INST. OF JUST. J. 42, 43 (2012), https://www.ncjrs.gov/pdffiles1/nij/238488.pdf (“A new study shows that nearly one-third of American adults have been arrested by the age of 23 . This record will keep many people from obtaining employment, even if they have paid their dues, are qualified for the job and are unlikely to reoffend.").

9 Id.

10 Sam Hananel, Updated EEOC Guidelines Make It Harder for Employers to Discriminate Against Former Criminals, HuFfingTON Post (Apr. 26, 2012, 12:20 PM), http://www.huffingtonpost. com/2012/04/26/updated-eeoc-guidelines_n_1456021.html.

11 About EEOC, U.S. EQUAL EMP. OPPORTUNITY COMM'N, http://www.eeoc.gov/eeoc/index.cfm (last visited Oct. 20, 2013).

12 See Laws Enforced by EEOC, U.S. EQUAL EMP. OPPORTUNITY COMM’N, http://www.eeoc. gov/laws/statutes/titlevii.cfm (last visited Apr. 9, 2015).

13 Int'1 Bros. of Teamsters v. United States, 431 U.S. 324, 335 n. 15 (1977).

14 Susan Adams, Background Checks on Job Candidates: Be Very Careful, ForBES (June 21, 2013, 11:56 AM), http://www.forbes.com/sites/susanadams/2013/06/21/background-checks-on-jobcandidates-be-very-careful/.

15 See Janell Ross, Criminal Background Checks Upend Job Search for Some Unemployed, HufFington POST (Mar. 24, 2011, 3:16 PM), http://www.huffingtonpost.com/2011/03/24/criminalbackground-check_n_840195.html (recounting the story of a job applicant whose job offer was rescinded after the employer discovered the applicant's prior wire fraud conviction). 
crime occurred, or "the nature and gravity of the offense." ${ }^{.16}$ Approximately 65 million U.S. adults - one in four Americans - have a criminal record. ${ }^{17}$ Consequently, a number of job applicants have trouble getting hired due to their criminal past. ${ }^{18}$ What's more is that these blanket criminal background policies are having a disparate impact on African-American and Hispanic job applicants, since they are arrested and convicted at rates higher than their white counterparts. ${ }^{19}$

An integral part of an ex-offender's reentry into the community, after having served time in prison, is the acquisition and maintenance of gainful employment. ${ }^{20}$ Obtaining employment helps ex-offenders feel as if they are once again a part of their community. ${ }^{21}$ It not only allows them to earn a living in an honest and legal manner, but it also aids in preventing recidivism. ${ }^{22}$ If employers are allowed to reject job applicants solely because of a criminal background, an ex-offender's re-integration into the community is likely to be unsuccessful. ${ }^{23}$ Not only will ex-offenders find themselves unemployed, but they will also have a greater chance of becoming recidivists who will return to prison. ${ }^{24}$ These recidivists will both increase the crime rates in our communities and increase the amount of tax dollars expended on maintaining our criminal justice system. ${ }^{25}$ Therefore,

16 See Consideration of Arrest and Conviction Records in Employment Decisions Under Title VII of the Civil Rights Act of 1964, U.S. EQUAL EMP. OPPORTUNITY COMM'N (Apr. 25, 2012), http://www. eeoc.gov/laws/guidance/arrest_conviction.cfm [hereinafter EEOC Guidance] ("A policy or practice requiring an automatic, across-the-board exclusion from all employment opportunities because of any criminal conduct is inconsistent with the Green factors [the nature and gravity of the offense or conduct; the time that has passed since the offense or conduct and/or completion of the sentence; and the nature of the job held or sought] because it does not focus on the dangers of the particular crimes and the risks in particular positions.").

17 Michelle Natividad Rodriguez \& Maurice Emsellem, 65 Million "Need Not Apply" The Case for Reforming Criminal Background Checks for Employment, THE NAT'L EMP. L. PROJECT 1, 1 (March 2011), http://nelp.org/content/uploads/2015/03/65_Million_Need_Not_Apply1.pdf.

18 Stan Alcorn, Job Seekers with Criminal Record Face Higher Hurdles, WNYC NEws (Jan. 17, 2013), http://www.wnyc.org/story/262814-blog-job-seekers-with-criminal-record-face-higher-hurdles/; Ross, supra note 15.

19 Criminal Justice Fact Sheet, NAACP, http://www.naacp.org/pages/criminal-justice-fact-sheet (last visited Nov. 23, 2013) ("Together, African Americans and Hispanics comprised 58\% of all prisoners in 2008, even though African Americans and Hispanics make up approximately one quarter of the US population.”).

20 Melinda Schlager, Rethinking the ReEntry Paradigm: A Blueprint For ACtion 73 (2013); MELVIN DELGADO, PRISONER REENTRY AT WORK 90 (2012).

21 DELGADO, supra note 20, at 95.

22 SCHLAGER, supra note 20, at 73.

23 See id.

24 See DELGADO, supra note 20, at 97-98; Swanson, supra note 1, at 77 ("The last two national recidivism studies of prisoner releases in 1983 and 1994 report that approximate two-thirds of released inmates were rearrested within 3 years of their release ....").

25 See Satoshi Kanazawa, When Crime Rates Go Down, Recidivism Rates Go Up, PsYchol. TODAY (Aug. 24, 2008), http://www.psychologytoday.com/blog/the-scientific-fundamentalist/200808/ 
this Comment argues that the EEOC should be able to enforce its Guidance against employers who reject job applicants based solely on their criminal history for two reasons: (1) because of the disparate impact it has on minority job applicants; and (2) because without the re-integration of exoffenders into our community, through the attainment of employment, these ex-offenders are likely to become recidivists who will have little chance at rehabilitation.

But what about the employer's prerogative? In our at-will employment system, employers may fire an employee for any (or no) reason, without incurring liability, so long as the reason for the discharge is not illegal or does not violate public policy. ${ }^{26}$ So is an employer's preference of not employing individuals with criminal backgrounds a permissible reason for discharging or failing to employ an employee under the at-will doctrine, or does it violate public policy norms? This Comment also proposes that despite the theory of the at-will system, there are instances where public policy concerns outweigh the employer's prerogative in firing or failing to hire someone with a criminal background. However, this Comment recognizes that there are instances where an employer's prerogative greatly outweighs the public policy interest of hiring individuals with criminal histories (for example, refusing to hire a sex offender as a school teacher). This Comment in no way proposes that employers must hire every individual with a criminal background, but instead proposes that each applicant's criminal background should be considered individually in light of the job sought. Simply said, if the past crime is not related to the job sought, or it does not indicate that the employer would be exposed to potential negligent hiring liability, the employer's prerogative is outweighed by the public policy interest of reintegrating ex-offenders into society by affording them legal means of employment. ${ }^{27}$

This Comment proceeds in three parts. Part I will discuss the evolution of the disparate impact theory and the birth and purpose of the EEOC's Guidance on the Consideration of Arrest Records in Employment Decisions. Part II will discuss the backlash and criticism the EEOC's Guidance has caused, and how the EEOC is using the Guidance to combat

when-crime-rates-go-down-recidivism-rates-go; DELGADO, supra note 20, at 90 ("It costs an estimated $\$ 69$ billion a year in state and federal dollars to maintain all the state prisons combined.").

26 John Bordeau \& Barbara J. VAN ARSDAle, Employment-At-Will Doctrine, 82 AM. JUR. 2D Wrongful Discharge $§ 1$ (2014).

27 See Ponticas v. K.M.S. Inv., 331 N.W. 2d 907, 913 (Minn. 1983) ("There are many persons ... who have prior criminal records but who are now good citizens and competent and reliable employees. Were we to hold that an employer can never hire a person with a criminal record at the risk of later being held liable for the employee's assault, it would offend our civilized concept that society must make a reasonable effort to rehabilitate those who have erred so they can be assimilated into the community."). 
disparate impact in the workplace. This section will also analyze how unemployed ex-offenders are more likely to re-offend, and how finding employment helps ex-offenders rebuild their lives and stay away from a life of crime. Moreover, this section will discuss how state legislatures are contributing to the ongoing problem of unemployed ex-offenders and recurring recidivists by excluding ex-offenders from practicing certain professions. Lastly, Part III will analyze where an employer's prerogative fits into this picture and whether employers have a duty to help remedy this ongoing phenomenon. This section will also analyze current solutions to the criminal background check controversy and propose additional methods of resolving this issue.

\section{BACKGROUND LAW}

\section{A. The Historical and Current State of the Law}

In 1964, Congress passed Title VII, making it unlawful for "an employer to fail or refuse to hire or discharge any individual, or otherwise discriminate against any individual with respect to compensation, terms, conditions, or privileges of employment, because of such individual's race, color, religion, sex, or national origin." ${ }^{28}$ This language indicated a prohibition of disparate treatment of persons because of their membership in a protected category. ${ }^{29}$ However, in Griggs v. Duke Power Co. ${ }^{30}$ the United States Supreme Court interpreted Title VII to proscribe both disparate treatment and disparate impact. ${ }^{31}$ The Supreme Court has defined disparate impact as "employment practices that are facially neutral in their treatment of different groups but that in fact fall more harshly on one group than another and cannot be justified by business necessity." 32 In other words, even if an employer has a facially-neutral policy or practice, if it has a disparate impact on a protected class, and it is not job related, the employer's policy or practice violates Title VII. ${ }^{33}$

In 1991, Congress codified the prohibition of employer practices and policies that have a disparate impact on members of a protected category:

An unlawful employment practice based on disparate impact is established...only if: a complaining party demonstrates that a respondent uses a particular employment practice that causes a

42 U.S.C. $\S 2000 \mathrm{e}-2(\mathrm{a})(1)(1964)$.

29 Terence G. Connor \& Kevin J. White, The Considerations of Arrest and Conviction Records in Employment Decisions: A Critique of the EEOC Guidance, 43 SETON HALL L. REV. 971, 977 (2013).

30401 U.S. 424 (1971).

$31 \quad I d$. at 436.

32 Int'l Bros. of Teamsters v. United States, 431 U.S. 324, 335 n.15 (1977).

33 Griggs, 401 U.S. at 436. 
disparate impact on the basis of race, color, religion, sex, or national origin and the respondent fails to demonstrate that the challenged practice is job related for the position in question and consistent with business necessity or the complaining party makes the demonstration... [that] an alternative employment practice exists and the respondent refuses to adopt such alternative employment practice. ${ }^{34}$

After codifying the prohibition again disparate impact, Congress did not define "business necessity" and left it to the courts to define the term. ${ }^{35}$ Gregory v. Litton Systems ${ }^{36}$ was one of the first cases to analyze a disparate impact claim involving an employer who refused to hire an applicant because of his arrest record. ${ }^{37}$ The job applicant in Gregory, Earl Gregory (Gregory), was African-American and had applied for employment as a sheet metal mechanic. ${ }^{38}$ Gregory was offered (and accepted) employment. ${ }^{39}$ The employer, however, had "a standard policy of not hiring applicants who had been arrested 'on a number of occasions' for things other than minor traffic offenses." ${ }^{40}$ Before commencing work, Gregory was required to fill out a "Preliminary Security Information" form, which required "a listing of all arrests other than those involving minor traffic offenses." " Gregory disclosed he had "been arrested [but not convicted] on fourteen different occasions in situations other than minor traffic incidents." ${ }^{, 2}$ As per the company's standard policy, the employer withdrew the job offer upon learning of Gregory's arrest record. ${ }^{43}$ Gregory subsequently filed suit against his potential employer alleging racial discrimination. ${ }^{44}$ The court found that "information concerning a prospective employee's record or arrests without convictions is irrelevant to [the employee's] suitability or qualification for employment." ${ }^{45}$ The court also reasoned that because African-Americans are arrested at rates higher than whites, any company policy that disqualified a prospective employee because of an arrest record

3442 U.S.C. $\$ 2000 \mathrm{e}-2(\mathrm{k})(1)(\mathrm{A})(\mathrm{i})$-(ii) (1991).

35 Connor \& White, supra note 29, at 979; see, e.g., Donnelly v. R.I. Bd. of Governors for Higher Educ., 929 F. Supp. 583, 593 (D. R.I. 1996), aff'd, 110 F.3d 2 (1st Cir. 1997) (noting the provisions relating to the "business necessity" defense in Title VII are ambiguous and stating that the term "“consistent with business necessity"... appears to require ... proof that the challenged practice is reasonably necessary to achieve an important business objective").

36316 F. Supp. 401 (C.D. Cal. 1970).

37 Id. at 402 .

38 Id.

39 Id.

40 Id.

41 Id.

42 Id.

43 See id.

44 Id.

45 Id. 
discriminated against African-Americans, even if the policy was applied equally to applicants of all races. ${ }^{46}$ Finding that the company's arrest policy was not excused or justified by any business necessity, the court found in Gregory's favor. ${ }^{47}$ However, the court did note that the employer should be allowed to "obtain and inspect information ... concerning the prosecution and trial of any prospective employee." ${ }^{, 48}$ In other words, while an employer may not deny employment based on arrest records, it may do so based on conviction records. ${ }^{49}$

An employer may use a job applicant's criminal background record as a factor in the hiring process only if it is supported by business necessity. ${ }^{50}$ In Green v. Missouri Pacific Railroad Company, ${ }^{51}$ the Eighth Circuit Court of Appeals echoed the court's reasoning in Gregory and held that absent a legitimate business necessity defense, rejecting a job applicant because of a criminal conviction record runs afoul of Title VII if it has a disparate impact on minorities. ${ }^{52}$ To meet the requirements of business necessity under Green, an employment policy has to advance the goal of "safety and efficiency," and there can be no "less restrictive alternative with a lesser racial impact." ${ }^{53}$ Namely, a legitimate business necessity for denying employment to an applicant with a criminal background would be if the criminal background indicates the applicant is unsuitable for the job. ${ }^{54}$

\section{B. The EEOC's Guidance on the Use of Arrest Records and Convictions in Employment Decisions}

In 1987, following the Green decision, the EEOC issued the "Policy Guidance on the Consideration of Arrest Records in Employment Decisions Under Title VII of the Civil Rights Act of 1964" $" 55$ (Guidance). The purpose of this policy was to set forth the EEOC's procedure for determining

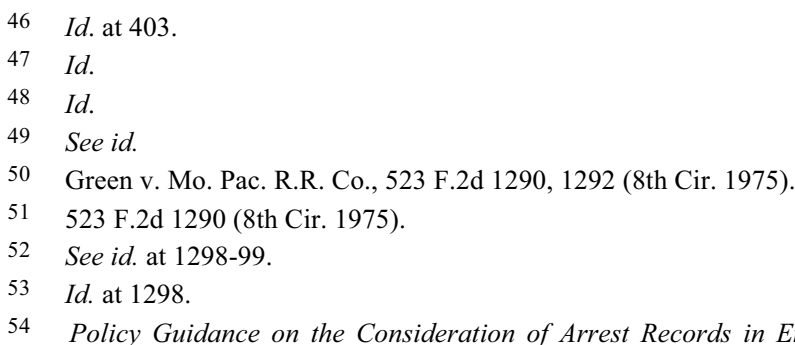
Title VII of the Civil Rights Act of 1964, as amended, 42 U.S.C. \$2000e et seq., U.S. EQUAL EMP. OPPORTUNITY COMM'N, (Sept. 7, 1990), http://www.eeoc.gov/policy/docs/arrest_records.html. For example, a job applicant's criminal conviction of sexually molesting a minor child is an indicator that the applicant is not suited to work at a childcare center. In this instance, the employer would be justified in using a criminal record as a basis for rejecting the job applicant as it is a business necessity to keep children safe and away from sexual predators.

55 Id. 
whether arrest records may be considered in employment decisions. ${ }^{56}$ The EEOC concluded that because the use of arrest records in employment decisions could have a disparate impact on certain protected groups, policies disqualifying applicants solely because of their arrest records could not stand. ${ }^{57}$ However, the EEOC noted that if an applicant's arrest record indicates that the applicant would be unsuitable for a particular position, the employer may deny employment to the applicant. ${ }^{58}$ Moreover, if the conduct for which the applicant was arrested is related to the job sought and occurred recently, the employer may exclude the applicant from employment. ${ }^{59}$ In essence, the EEOC memorialized the Green factors as the criterion to be considered when determining whether a conviction demonstrates that an applicant is unsuitable for the job. ${ }^{60}$ The factors employers should consider when determining whether to hire an applicant with a criminal history are: (1) "the nature and gravity of the offense or offenses;" (2) "the time that has passed since the conviction;" and (3) "the nature of the job held" or sought. ${ }^{61}$

In 2012, the EEOC revised and updated the Guidance after meeting with employers, ex-offenders, and federal agency directors to discuss the use of criminal history information in the employment application process. ${ }^{62}$ In revising its Guidance, the EEOC incorporated sociological and criminologist research, court rulings, and state and federal laws in order to help employers understand the consequences of using criminal background checks in employment decisions. ${ }^{63}$ The EEOC did this as a result of the legal and social changes that have occurred since it first issued the Guidance in $1987 .^{64}$ While the EEOC's objective has been to combat the disparate impact criminal background policies have on minorities, critics and opponents of the Guidance have hindered the Commission's efforts. ${ }^{65}$

$\begin{array}{ll}56 & I d . \\ 57 & I d . \\ 58 & I d . \\ 59 & I d . \\ 60 & \text { EEOC Guidance, supra note } 16 . \\ 61 & \text { Id. (quoting Green v. Mo. Pac. R.R. Co., } 549 \text { F.2d 1158, } 1160 \text { (8th Cir. 1977)). } \\ 62 & \text { What You Should Know About the EEOC and Arrest and Conviction Records, U.S. EQUAL }\end{array}$ EMP. OPPORTUNITY COMM'N, http://www.eeoc.gov/eeoc/newsroom/wysk/arrest_conviction_records . cfm (last visited Oct. 20, 2013).

$\begin{array}{ll}63 & I d . \\ 64 & I d . \\ 65 & \text { See generally infra note } 66 .\end{array}$ 


\section{ANALYSIS}

\section{A. The EEOC's Updated Guidance Causes a Stir}

Since its latest update in 2012, the Guidance has returned into the spotlight and has been the source of much talk and controversy. ${ }^{66}$ The EEOC itself has experienced backlash and has come under fire by numerous critics. ${ }^{67}$ One critic has even questioned that if the United States government can check its employees' criminal backgrounds, then "why can't private employers?" 68 The adverse response to the EEOC's updated guidance even led nine state attorney generals to address a letter to EEOC Chair Jacqueline A. Berrien advocating for the Commission to reconsider its position on the matter. ${ }^{69}$ The attorneys general believe that the EEOC's guidance serves as an "illegitimate expansion of Title VII to former criminals," is a "gross federal overreach," and imposes a financial burden on employers by "forcing [them] to undertake more individualized assessments ... [of job applicants]. ${ }^{, 70}$ In response, Berrien addressed the concerns of the attorneys' general, and clarified that it is not (nor has the EEOC suggested) illegal for employers to conduct criminal background

66 See, e.g., Todd Frederickson, EEOC's Criminal Background Check Policy Under Fire, DENVER BUS. J. (Jan. 22, 2014, 6:00 AM), http://www.bizjournals.com/denver/blog/broadway_17th/ 2014/01/eeocs-criminal-background-check.html?page=all; Jeanna Smialek, Ex-Convict Hire Hurdle Draws U.S. Suits Against Employers, BLOOMBERG (Jan. 31, 2014), http://www.businessweek.com/news/ 2014-01-31/ex-convict-hire-hurdle-draws-u-dot-s-dot-suits-against-employers; Companies Rethink Hiring Policies for Former Criminals, InDianapolis BuS. J. (Feb. 7, 2014), http://www.ibj.com/ companies-rethink-hiring-policies-for-former-criminals/PARAMS/article/46052.

67 Christopher J. DeGroff \& Paul Kehoe, The Background Backlash Continues- Texas Sues the EEOC Over Its Criminal Background Guidance, LEXOLOGY (Nov. 6, 2013), http://www.lexology.com/ library/detail.aspx?g=f74de8a0-7173-414d-8a5d-13f236309f91 ("The State of Texas sued the EEOC in the Northern District of Texas seeking declaratory and injunctive relief against the EEOC for issuing its 2012 arrest and conviction guidance.... The Texas complaint argued that the EEOC did not have the authority to issue this rule."); Texas v. EEOC Complaint for Declaratory and Injunctive Relief, available at https://www.texasattorneygeneral.gov/newspubs/releases/2013/2013-11-04-EEOC-Complaint-FM. pdf; see infra note 69, at 2 ("[Y] our enforcement guidance [is] misguided and a quintessential example of gross federal overreach.”); EEOC v. Freeman, No. RWT 09cv2573, 2013 WL 4464553, at *11 (D. Md. Aug. 9, 2013) (describing the EEOC's attempt to establish that an employer's hiring policy involving criminal background checks resulted in a disparate impact as "laughable").

68 Daniel Fisher, The Government Checks Criminal Records. Why Can't Private Employers?, FORBES (June 21, 2013, 7:36 AM), http://www.forbes.com/sites/danielfisher/2013/06/21/thegovernment-checks-criminal-records-why-cant-private-employers/.

69 Letter from Patrick Morrisey, Att'y Gen., State of W. Va., et al., to Jacqueline A. Berrien, Chair, U.S. Equal Emp't Opportunity Comm'n (July 24, 2013), available at https://doj.mt.gov/wpcontent/uploads/EEOC-Letter-Final.pdf. Nine state attorneys general were signatories to this letter: Patrick Morrisey, West Virginia Attorney General, Luther Strange, Alabama Attorney General, John Suthers, Colorado Attorney General, Samuel S. Olens, Georgia Attorney General, Derek Schmidt, Kansas Attorney General, Tim Fox, Montana Attorney General, John Bruning, Nebraska Attorney General, Alan Wilson, South Carolina Attorney General, and John E. Swallow, Utah Attorney General.

$70 \quad$ Id. at 3-4. 
checks on job applicants or its employees. ${ }^{71}$ Berrien also clarified that the Guidance does not require employers to individually assess all applicants and employees, but instead "encourages a two-step process" which calls for: (1) "a 'targeted' screen" of criminal records (which considers "the nature of the crime, the time lapsed, and the nature of the job"); and (2) "an individualized assessment for those [applicants] who were screened out" in the targeted screening process. ${ }^{72}$ Most importantly, Berrien highlighted that the use of individual assessments can help employers avoid liability under Title VII when it is unable to show that its targeted screening process is "job related and consistent with business necessity." 73

\section{B. The EEOC Takes Legal Action Against Companies in Violation of the Guidance}

The EEOC's most recent effort at taking legal action against an employer with a blanket criminal background check policy was in 2013 in EEOC v. Freeman.$^{74}$ In Freeman, the EEOC alleged that the employer's use of criminal history as a hiring criterion had a disparate impact on AfricanAmerican, Hispanics, and male job applicants. ${ }^{75}$ The court granted summary judgment for the employer, finding that the EEOC was unable to "isolate a specific employment practice that allegedly caused a disparate impact." "76 Additionally, the court found that the EEOC's expert reports and conclusions were unreliable and deemed them to be "laughable." "Freeman turned out to be a failed attempt at holding an employer civilly liable for its inherently discriminatory criminal background policy. ${ }^{78}$

While the EEOC was unsuccessful in its lawsuit in Freeman, it was successful in settling a case with Pepsi Beverages (Pepsi). ${ }^{79}$ The EEOC's investigation concluded that over 300 African-Americans were denied employment under Pepsi's criminal background check policy that excluded

71 Letter from Jacqueline A. Berrien, Chair, U.S. Equal Emp't Opportunity Comm'n, to Patrick Morrisey, Att'y Gen., State of W. Va., et al. (Aug. 29, 2013), available at http://www.eeoc.gov/eeoc/ newsroom/wysk/upload/EEOC-Response-to-AG-Letter.pdf.

$72 \quad I d$. at 3.

$73 \quad I d$. at 4.

74 EEOC v. Freeman, No. RWT 09cv2573, 2013 WL 4464553, at*1 (D. Md. Aug. 9, 2013).

75 Id.

$76 \quad I d$. at $* 2$.

77 Id. at $* 8-11$.

78 Matthew R. Korn, Strike Two-The EEOC's Failed Attempts to Limit Background Checks, MARTINDALE (Oct. 4, 2013), http://www.martindale.com/labor-employment-law/article_Fisher-PhillipsLLP_1986532.htm.

79 Pepsi to Pay \$3.13 Million and Made Major Policy Changes to Resolve EEOC Finding of Nationwide Hiring Discrimination Against African Americans, U.S. EQUAL EMP. OPPORTUNITY COMM'N (Jan. 11, 2012), http://www.eeoc.gov/eeoc/newsroom/release/1-11-12a.cfm. 
job applicants who had been arrested but not yet convicted. ${ }^{80}$ Pepsi agreed to pay $\$ 3.13$ million and offer jobs to those affected by the company's criminal background check policy. ${ }^{81}$ Similarly, the EEOC was also successful in a settlement agreement with J.B. Hunt Transport (J.B. Hunt) in an alleged disparate impact criminal background check case. ${ }^{82}$ In that case, an African-American job applicant claimed he was denied employment by J.B. Hunt based on a criminal conviction record that was not related to the duties of the job he sought. ${ }^{83}$ As part of the settlement agreement, J.B. Hunt agreed to review, revise, and provide training on its hiring policies and practices, in order to comply with the EEOC's Guidance. ${ }^{84}$ The EEOC estimated that approximately 14,000 employees were affected by J.B. Hunt's criminal background policy. ${ }^{85}$

Shortly after revising its Guidance in 2012, the EEOC filed suits against Dollar General and BMW for its use of criminal background checks, which had a disparate impact on African-American and Hispanic employees. ${ }^{86}$ The EEOC asserted that "Dollar General condition[ed] all of its job offers on criminal background checks, which result[ed] in a disparate impact against blacks." ${ }^{\circledR 7}$ The complaint filed against Dollar General asserted that:

Pursuant to [Dollar General's] criminal conviction policy, once an applicant is given a job offer, the store manager submits information on the applicant to a third party vendor-General Information Services, Inc. (GIS) - which then conducts a criminal background check on the applicant.... If the result is "Fail," the information is conveyed by GIS to the district manager .... That district manager then notifies the store manager that the applicant cannot be hired.... [Dollar General's] utilization of its criminal convictions policy has not been demonstrated to be and is not job-related and consistent with business necessity ... [ [T] he policy as applied does not provide for an individualized assessment for those applicants who receive a "Fail" result to determine if the reason for the disqualification is job-related

82 J.B. Hunt Agrees to Settle EEOC Race Discrimination Case Regarding Criminal Convictions Records, U.S. EQUAL EMP. OPPORTUNITY COMM'N (June 28, 2013), http://www.eeoc.gov/eeoc/ newsroom/release/6-28-13c.cfm.

83 Id.

$84 \quad I d$.

85 Id.

86 EEOC Files Suit Against Two Employers for Use of Criminal Background Checks, U.S. EQUAL EMP. OPPORTUNITY COMM'N (June 11, 2013), http://www.eeoc.gov/eeoc/newsroom/release/611-13.cfm [hereinafter Two Suits].

87 Id. 
and consistent with business necessity. ${ }^{88}$

Some of the felony and misdemeanor convictions that Dollar General believes call for job disqualification include flagrant non-support, possession of drug paraphernalia, illegal dumping, improper supervision of a child, reckless driving, and failure to file an income tax return. ${ }^{89}$ The EEOC alleged that of all the job offers made by Dollar General between January 2004 and April 2007, approximately seven percent of non-black employees were terminated for having a criminal background while ten percent of black employees were fired for "failing the background check." 90 The disparity in the rates at which black and non-black employees were fired due to the company's criminal background policy was significant enough for the EEOC to file a disparate impact suit against Dollar General. ${ }^{91}$ At the time of this writing, the suit against Dollar General remains on the docket of the United States District Court for the Northern District of Illinois, Eastern Division.

Similar to the complaint filed against Dollar General, the complaint filed against BMW alleged that the company was using criminal background checks to screen out and terminate African-American employees. ${ }^{92}$ The employees at issue in this case worked for UTi Integrated Logistics (UTi), which provided logistics services to BMW. ${ }^{93}$ The UTi employees worked in a BMW owned warehouse that was located inside the BMW facility. ${ }^{94}$ In 2008, UTi's contract with BMW ended. ${ }^{95}$ BMW then contracted with another contractor to replace UTi's services. ${ }^{96}$ BMW wanted to retain as many UTi employees as possible in order to avoid disruption at its facility. ${ }^{97}$ The former UTi employees were required to apply for employment directly with BMW, ${ }^{98}$ which included performing background checks on every UTi employee applying for a "transition of employment position." "99 The new contractor performed background checks on almost 645 UTi employees. ${ }^{100}$ As a result of these checks, it was

88 EEOC v. Dolgencorp LLC Compl. at 3, available at http://online.wsj.com/public/resources/ documents/DollarGeneralComplaint20130611.pdf [hereinafter Dollar General Compl.].

$\begin{array}{ll}89 & I d . \\ 90 & I d . \\ 91 & I d . \\ 92 & I d \text {. at } 2 . \\ 93 & I d . \\ 94 & I d \text {. at } 3 . \\ 95 & I d . \text { at } 4 . \\ 96 & I d . \\ 97 & I d . \\ 98 & \text { See id. } \\ 99 & I d . \\ 100 & I d .\end{array}$


discovered that 88 UTi employees "had criminal convictions in violation of BMW's criminal conviction policy." 101 As a result of this policy, the eightyeight employees were rejected from employment with BMW. ${ }^{102}$ Of those eighty-eight employees, seventy (80\%) were black and only eighteen $(20 \%)$ were non-black. ${ }^{103}$

BMW's criminal background check policy excludes individuals with convictions of certain crimes: "murder; assault \& battery; rape; child abuse; domestic violence; manufacturing of drugs; distribution of drugs; and weapons violations." 104 The policy also "excludes from employment individuals with criminal convictions involving theft, dishonesty, and moral turpitude." 105 BMW's criminal background policy does not distinguish between felony and misdemeanor convictions. ${ }^{106}$ Nonetheless, BMW's criminal background policy seems to exclude job applicants on the basis of violent or drug related crimes. ${ }^{107}$ This is more rational than Dollar General's policy of excluding applicants on the basis of crimes such as illegal dumping and failure to file an income tax return, which are non-indicative of unsuitability for the job, or potential employer liability for negligent hiring. ${ }^{108}$ At the time of this writing, the EEOC's suit against BMW remains on the docket of the United States District Court for the District of South Carolina, Spartanburg Division.

\section{High Unemployment Rates of Ex-offenders Translate into High Recidivism Rates}

Another reason why the EEOC should be able to enforce its Guidance (aside from disparate impact concerns) is because ex-offenders, who remain



In determining whether a person is suitable for Federal employment, only the following factors will be considered as basis for finding a person unsuitable ...

(1) Misconduct or negligence in employment; (2) Criminal or dishonest conduct; (3) Material, intentional false statement, or deception or fraud in examination or appointment; (4) Refusal to furnish testimony... (5) Alcohol abuse ... of a nature and duration that suggests that the applicant or appointee would be prevented from performing the duties of the position in question, or would constitute a direct threat to the property or safety of the applicant or appointees or others; (6) Illegal use of narcotics, drugs, or other controlled substances; (7) Knowing and willful engagement in acts or activities designed to overthrow the U.S. Government by force; and (8) Any statutory or regulatory bar which prevents the lawful employment of the person involved in the position in question. 
unemployed for long periods after release, are more likely to re-offend and return to prison than ex-offenders who obtain employment after release. ${ }^{109}$ Research indicates that obtaining a job post-release lessens the chances of re-offending. ${ }^{110}$ Thus, in essence, companies who fail to hire applicants, or fire its employees based on their blanket criminal background policies, are contributing to the nation's crime and recidivism rates.

An additional factor that gives rise to the disparate impact caused by the consideration of criminal records in the employment context is that employers are more likely to hire white ex-offenders than black exoffenders. ${ }^{111}$ A study conducted in 2005 by sociologist Devah Pager showed that employers tend not to hire applicants with a criminal history. ${ }^{112}$ What's more, those employers that did hire applicants with criminal backgrounds disproportionately hired more whites with criminal backgrounds than blacks with the same criminal backgrounds. ${ }^{113}$ The study involved two black and two white job applicants. ${ }^{114}$ Two applicants (one white and one black) were "assigned" a criminal background consisting of a felony drug conviction and eighteen months of served prison. ${ }^{115}$ The other two applicants (one white and one black) did not possess a criminal background. ${ }^{116}$ All four applicants applied for entry-level positions (jobs requiring no previous work experience and a high school diploma) ${ }^{117}$ with 350 employers. ${ }^{118}$ The results of this study indicated that blacks with criminal backgrounds are less likely to receive employment than whites with the same criminal background. ${ }^{119}$ Thirty-four percent of white applicants with no criminal background record received callbacks from employers, while only fourteen percent of black applicants with no criminal background were called for an interview. ${ }^{120}$ Astoundingly, seventeen percent of white applicants with a criminal record received callbacks, while a mere five percent of black applicants with the same criminal record were called by employers for a job interview. ${ }^{121}$ This study shows that in addition

109 Christy A. Visher et al., Ex-offender Employment Programs and Recidivism: A Meta-analysis, 1 J. EXPERIMENTAL CRIMINOLOGY 295, 295 (2005).

110 Id.

111 See generally DeVAh PAgER, MARKED: RACE, CRIME, AND FINDING WORK IN AN ERA OF MASS INCARCERATION 58-85 (2007).

112 Id.

113 Id. at 67, 70.

$114 I d$. at 59.

115 Id. at 61.

$116 I d$. at 60.

117 Id. at 59.

118 Id. at 60.

119 Id. at 67, 70.

120 Id.

121 Id. 
to the existence of a criminal background, employers will also take race into account when deciding to hire an ex-offender. ${ }^{122}$ This demonstrates that the disparate impact caused by the consideration of criminal backgrounds during the employment process is exacerbated by employers' racial attitudes and unlawful considerations.

\section{Employers' Concerns for Negligent Hiring Liability}

Ex-offenders face two primary challenges in obtaining post-release employment: (1) a criminal record makes for an unattractive job candidate; and (2) incarceration erodes job skills and weakens any social ties to those who could provide ex-offenders with employment opportunities. ${ }^{123}$ Employers may be wary of hiring candidates with criminal records because they might perceive ex-offenders as individuals who lack trustworthiness. ${ }^{124}$ This is a particular concern for employers working in areas that require customer contact or the handling of money, which requires the employment of honest and trustworthy employees. ${ }^{125}$ Thus, most employers rely on criminal backgrounds to determine their potential liability for negligent hiring. ${ }^{126}$

Employers may be wary of hiring ex-offenders because they pose a much higher liability to employers than employees without criminal records. ${ }^{127}$ For example, in McLean v. Kirby Company, Michael Molachek was hired as a door-to-door salesman without verification of his criminal

122 See id.

123 PRISONER REENTRY AND CRIME IN AMERICA 220 (Jeremy Travis \& Christy Visher eds., 2005) [hereinafter PRISONER REENTRY].

124 Harry J. Holzer et al., Employment Barriers Facing Ex-Offenders, URBAN INST. REENTRY ROUNDTABLE 1, 8 (May 19, 2003), http://www.urban.org/UploadedPDF/410855_holzer.pdf.

125 Id.

126 See Helen Gaebler, Criminal Records in the Digital Age: A Review of Current Practices and Recommendations for Reform in Texas, 17 (Mar. 2013), available at http://www.utexas.edu/law/centers/ publicinterest/research/criminalrecords_report.pdf ("Employers often claim that they will be subject to negligent hiring lawsuits if they hire persons with criminal histories.").

127 See, e.g., Tallahassee Furniture Co. v. Harrison, 583 So. 2d 744, 747 (Fla. 1st DCA 1991) (finding employer liable for negligently hiring a furniture delivery man with an extensive criminal record including convictions for cutting his former wife in the face with a knife and multiple charges of battery. After hiring the defendant as a delivery man without checking his criminal background, defendant brutally attacked a customer at her home causing permanent scaring, the loss of one eye, and partial paralysis in the customer's hands.); Deerings W. Nursing Ctr., Div. of Hillhaven Corp. v. Scott, 787 S.W. 2d 494, 495 (8th Tex. App. 1990) (finding nursing home liable for negligently hiring unlicensed nurse employee that had 56 prior convictions for theft, without conducting a criminal background check. The employee attacked, slapped, and pinned to the ground an eighty-year-old woman visiting her brother in the nursing home.); Ponticas v. K.M.S. Inv., 331 N.W.2d 907, 911-14 (Minn. 1983) (finding employer liable for hiring an apartment manager, who had previously been convicted of armed robbery and burglary, without conducting a criminal background check. During a maintenance call, defendant raped an apartment tenant.). 
background. ${ }^{128}$ A year prior to his employment as a salesman, Molachek was convicted of assault and weapon charges and had been charged of criminal sexual conduct in the third degree. ${ }^{129}$ Shortly after commencing his employment as a salesman, Molachek visited the home of Linda McLean to demonstrate a vacuum cleaner he was selling. ${ }^{130}$ Upon entering McLean's home, Molachek assaulted and raped McLean. ${ }^{131}$ The trial court found that Molachek's employer owed a duty to McLean, stating:

The court is of the opinion that [McLean] has established a duty on the part of [the employer] to use reasonable care in seeing that its distributors employ reasonable care in the checking or investigating of the background and fitness of prospective door-to-door salespersons so as to minimize the risk of harm to others. ${ }^{132}$

The jury found the employer had negligently hired Molachek for failing to conduct a proper criminal background check and consequently awarded McClean $\$ 150,000$ in damages. ${ }^{133}$

Not surprisingly, the liabilities associated with negligent hiring are a major deterrent to employers when considering whether to hire an applicant with a prior criminal record. ${ }^{134}$ However, some courts have rejected the notion that employers have a duty to solicit information about an applicant's criminal record, even if the employee will have regular contact with members of the public. ${ }^{135}$ The reason for this is to prevent ex-offenders from being rejected from jobs based solely on their criminal past, and thus being prevented from rehabilitating themselves and reentering our

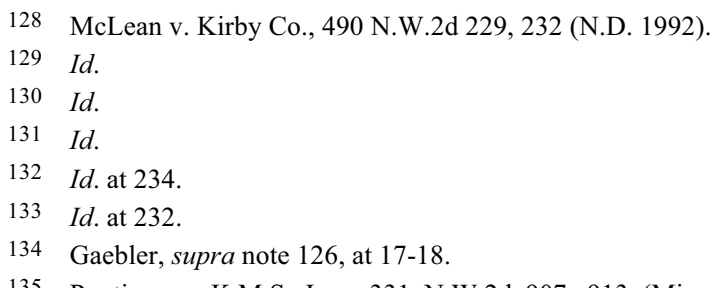

135 Ponticas v. K.M.S. Inv., 331 N.W.2d 907, 913 (Minn. 1983) (internal citations omitted) ("[W]e reject the contention that, as a matter of law, there exists a duty upon an employer to make an inquiry as to a prospective employee's criminal record even where it is known that the employee is to regularly deal with members of the public. If the employer has made adequate inquiry or otherwise has reasonably sufficient basis to conclude the employee is reliable and fit for the job, no affirmative duty rests on him to investigate the possibility that the applicant has a criminal record."); Ernst v. Parkshore Club Apartment Ltd. P'ship, 863 F. Supp. 651, 656-57 (N.D. Ill. 1994) (granting summary judgment to employer on a negligent hiring claim noting that an employee's "arrest record would tell an employer nothing regarding his ability to perform [] work. Even if [the employer] had known about [the employee's] arrest record, his arrest record does not make the [employee's misconduct] any more foreseeable. [A]n inquiry into [an employee's criminal background] would operate against [the] public policy of promoting the rehabilitation of former criminal offenders."). But see Frith v. Fairview Baptist Church, No. 05-01-01605-CV, 2002 WL 1565664, at *3 (Tex. App. July 17, 2002) (holding that a Church had a duty to check the criminal background of persons it put in charge of the children's Sunday school classes). 
communities where they may rebuild their lives. ${ }^{136}$ In Ponticas v. K.M.S. Investment, a tenant was raped by the manager of her apartment complex. ${ }^{137}$ The tenant brought charges against the owner of the apartment complex for negligently hiring Dennis Graffice, the apartment manager who attacked her, without conducting a criminal background check. ${ }^{138}$ Prior to his employment at the apartment complex, Graffice had been charged and convicted of burglary and receiving stolen property. ${ }^{139}$ Shortly after being released from serving four and a half months in jail, Graffice was charged and convicted of armed robbery and burglary and sentenced to prison. ${ }^{140}$ After his release, Graffice and his wife answered an ad placed in the newspaper seeking a resident manager at an apartment complex. ${ }^{141}$ Graffice completed the job application and indicated that he had been convicted of a crime related to traffic tickets, but he made no mention of his prior burglary and armed robbery convictions. ${ }^{142}$ The employer did not inquire about Graffice's criminal record any further as she did not consider traffic tickets to be a crime. ${ }^{143}$ At trial, Graffice testified that he did not disclose his felony convictions because he wanted the job, and if he had been asked to sign an authorization form releasing his criminal records, he would have refused. ${ }^{144}$

The Supreme Court of Minnesota decided the apartment complex owner (the employer) owed a duty to exercise care when hiring an apartment complex manager, since the job position required being in contact with the tenants of the complex. ${ }^{145}$ In deciding whether the employers breached their duty by subjecting the tenants to a foreseeable injury by employing an "incompetent person," the court considered whether the employer "knew or should have known" of the incompetence, but nonetheless hired the employee. ${ }^{146}$ The court noted that an employer must conduct a "reasonable investigation" of all job applicants. ${ }^{147}$ Once an employer has conducted a reasonable investigation indicating that the employee is "reliable and fit for the job," the employer has no affirmative duty to investigate into the applicant's criminal background. ${ }^{148}$ The court

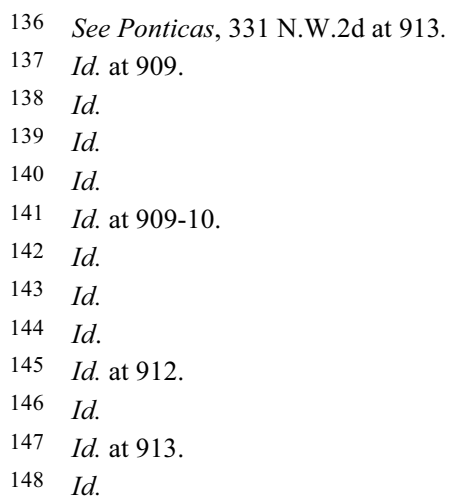


gave a public policy reason for its rationale:

There are many persons ... who have prior criminal records but who are now good citizens and competent and reliable employees. Were we to hold that an employer can never hire a person with a criminal record at the risk of later being held liable for the employee's assault, it would offend our civilized concept that society must make a reasonable effort to rehabilitate those who have erred so they can assimilate into the community. [A] rule mandating an independent criminal history investigation would counter the many worthwhile efforts of individuals, organizations and employers to aid former offenders to reestablish good citizenship, the sine qua non of which is gainful and productive employment. ${ }^{149}$

The court, however, found that the employer had not conducted a reasonable inquiry into Graffice's competence for the job, as it did not contact the references listed on Graffice's application. ${ }^{150}$ Had the employer contacted the references listed, it would have discovered that the references were Graffice's mother and sister, and not people Graffice had done tree service work for as he had indicated on his application. ${ }^{151}$ The court reasoned that contacting these "references" would have demonstrated that Graffice had lied on his application, thus making his competence for the job questionable and prompting further investigation into his background. ${ }^{152}$ In essence, the court found that the employer had breached its duty of care to the tenants of its apartment complex not because it failed to inquire into Graffice's criminal background, but because it failed to make a "reasonable investigation" into Graffice's character and thus, his competence for the job. ${ }^{153}$

An employer's potential liability for negligent hiring may be a factor in the unemployment rates of ex-offenders. ${ }^{154}$ Ex-offenders are less likely to receive employment in comparison to other members of disadvantaged groups. ${ }^{155}$ Surveys indicate that ninety percent of employers are willing to hire a welfare recipient, while only about forty percent are willing to hire an ex-offender. ${ }^{156}$ However, surveys also indicate employers are willing to hire ex-offenders in certain circumstances. ${ }^{157}$ Employers are open to hiring ex-

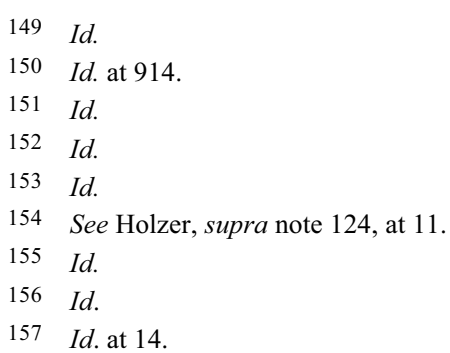


offenders that have been referred by an intermediary referral agency, if their prior offenses were non-violent, or if the ex-offender has gained meaningful work experience since being released from prison. ${ }^{158}$ Thus, helping to increase the number of ex-offenders referred by a referral agency, who have meaningful work experience, may increase the employment rates of exoffenders.

\section{E. Work Works}

Employment directly and positively affects recidivism. ${ }^{159}$ At least one scholar has suggested that employment can have a positive impact on exoffenders in such a way as to reduce the likelihood that they will reoffend. ${ }^{160}$ This is because work, just as other pro-social behaviors, allow for contact with persons who have a similar work ethic and thus have a tendency to influence the ex-offender into developing the same positive work ethics. ${ }^{161}$ For ex-offenders, employment does much more than keep them away from a life of crime and from reentering prison. ${ }^{162}$ The benefits of employment lead to increased self-esteem, attachment to the community, and a sense of belonging. ${ }^{163}$

Obtaining employment post-incarceration is more than securing a legal means of income; it is a form of "informal social control that may inhibit criminal behavior." 164 Employment may discourage ex-offenders from reengaging in criminal activity by altering their social networks and changing their routine activities. ${ }^{165}$ This, in turn, would provide ex-offenders with the social control that may help them become law-abiding citizens. ${ }^{166}$ It has been suggested that "ex-offenders who find quality work are likely to develop pro-social identities that may supplant or overshadow the salience of existing identities as rule-violators, troublemakers, or criminals." $" 167$

The high cost of recidivism is a factor that must be considered in the debate of employing ex-offenders. Unemployed ex-offenders have a higher chance of reoffending and returning to prison. ${ }^{168}$ The costs associated with

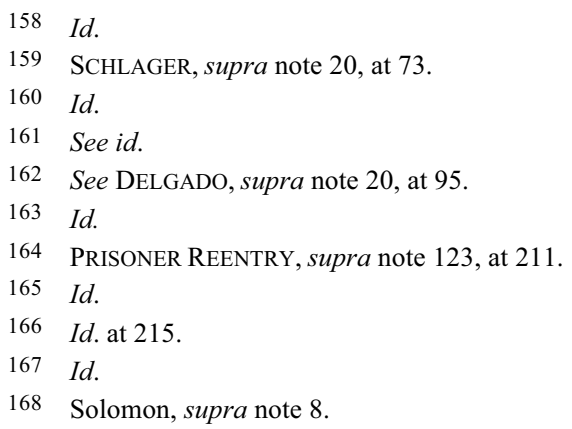


recidivism are astonishing. ${ }^{169}$ In the Southern District of Alabama alone, between 2008 and 2010, 328 ex-offenders returned to prison. ${ }^{170}$ Returning these ex-offenders to prison cost Alabama taxpayers approximately \$27 million. ${ }^{171}$ Had these ex-offenders remained out of prison on supervised released, it would have cost taxpayers only $\$ 1$ million. ${ }^{172}$ The high costs associated with re-offending individuals call for a serious consideration of implementing alternative remedies by which ex-offenders can remain out of prison. ${ }^{173}$ Namely, providing ex-offenders with the opportunity to gain employment despite their criminal background is a step in the right direction to redress the increasing costs of the criminal justice system. ${ }^{174}$

Without employment, ex-offenders are not only exposed to the risk and costs of re-offending, but they also contribute to the growing costs of social welfare programs. ${ }^{175}$ It is estimated that each year approximately two million workers are unemployed as the result of a felony conviction. ${ }^{176}$ And if these ex-offenders depend on government assistance, their unemployment costs taxpayers an additional $\$ 4$ billion dollars each year. ${ }^{177}$ The continued increased costs of social welfare programs are yet another consequence of denying employment to ex-offenders. ${ }^{178}$

\section{COMMENTARY}

\section{A. State Legislatures Are Part of the Problem}

The EEOC's Guidance targets private employers (in addition to

169 Project Hope Alabama Ex-Offender Re-Entry Initiative, U.S. DEP'T OF JUST., http://www. justice.gov/usao/als/rei.html (last visited Aug. 30, 2014).

170 Id.

171 Id.

$172 I d$.

173 See id

174 States can provide ex-offenders with the opportunity to gain employment by providing them with educational opportunities while in prison. See Tabitha Cohen, Education Programs in Florida Would Reduce Recidivism, Costs to Taxpayers, Sun SENTINEL (Dec. 30, 2011), http://articles.sunsentinel.com/2011-12-30/news/fl-prisons-recidivism-cohen-1230-20111230_1_prisons-offer-recidivismflorida-prison. ("[T]he average cost to house an inmate in a Florida prison as of 2011 is about $\$ 19,500$ annually. Corrections officers are paid about $\$ 30,800$ annually .... [E]ducation is an effective way to lower prison costs. In addition, with certain types of prison education programs, [the savings create] a need for fewer officers and in 'reducing recidivism in the long run."')

175 Saki Knafo, Employment Discrimination Pushes Felons Onto Food Stamp Rolls, Increasing Program Costs, HufFingTON PosT (July 11, 2013, 7:30 AM), http://www.huffingtonpost.com/2013/07/ 11/food-stamps-felons_n_3574412.html ("By refusing to hire people who have been convicted of crimes, employers may be adding billions of dollars to the total costs of the country's ballooning food assistance program.”).

176 Id.

177 Id.

178 See id. 
federal, state, and local governments) to "eliminate unlawful discrimination in employment screening, for hiring or retention," based on an applicant or employee's criminal background. ${ }^{179}$ In other words, the Guidance prevents employers from excluding applicants from a job solely based on their criminal backgrounds. ${ }^{180}$ But what happens when the state itself prohibits ex-offenders from practicing certain professions? Is this permissible, or does it run afoul of the EEOC's Guidance? Numerous states restrict exfelons from holding certain occupational licenses. ${ }^{181}$ Alaska prohibits a person convicted of a crime involving moral turpitude from holding a real estate appraiser certificate. ${ }^{182}$ Ohio refuses to renew, and may suspend or revoke, a barber's license if convicted or pleads guilty to any felonious crime. ${ }^{183}$ In New Jersey, a healthcare professional may have her license application denied if the applicant has a criminal history record (which may include arrests without convictions). ${ }^{184}$ These state restrictions are similar to the blanket criminal background policies the EEOC is targeting. ${ }^{185}$

Individuals affected by these all-inclusive occupational license barring statues have filed suits claiming that they should not have had their license revoked because the crime they committed is unrelated to the nature of their occupation. ${ }^{186}$ In Wendte v. State Board of Real Estate Appraisers, Ronald Wendte, a real estate appraiser, "was convicted of first-degree theft for stealing $\$ 250,000$ from three children's sports programs" in which he was a volunteer. ${ }^{187}$ As a result of the conviction, which was classified as a crime involving moral turpitude, the Alaska Board of Certified Real Estate

179 EEOC Guidance, supra note 16.

$180 \quad I d$

181 See Bruce May, The Character Component of Occupational Licensing Laws: A Continuing Barrier to the Ex-Felon's Employment Opportunities, 71 N.D. L. REV. 187, 193 (1995).

182 ALASKa STAT. § 08.87.110(a)(4) (West 2013).

183 OHIO REV. CODE ANN. § 4709.13 (B)(1) (West 2011).

184 N.J. Stat. ANN. § 45:1-29(a) (West 2005); see Elena Saxhouse, Note, Unequal Protection: Comparing Former Felons' Challenges to Disenfranchisement and Employment Discrimination, 56 StAN. L. Rev. 1597, 1613 (2004).

185 See Ron and Caryl Krannich, Legal Restrictions on Ex-Offenders, THE EX-OFFENDER'S JOB HUNTING GUIDE, available at http://www.exoffenderreentry.com/barriers_overcome/legal_restr.html (last visited Feb. 15, 2014).

186 See, e.g., Ake v. Bureau of Prof'1 \& Occupational Affairs, 974 A.2d 514 (Pa. Commw. Ct. 2009) (certified public accountant appealed the revocation of his professional license after being convicted of a hate crime, arguing the nature of the crime was unrelated to his ability to perform the responsibilities of a public accountant); Sullar v. Bd. of Registered Nursing, 205 Cal. App. 4th 1195 (2012) (nurse appealed revocation of professional license after being convicted of driving under the influence, arguing there is no nexus between the functions and duties of a nurse and an alcohol related conviction); Griffths v. Super. Ct., 96 Cal. App. 4th 757 (2002) (medical doctor appealed the revocation of his medical license after being convicted of driving under the influence, arguing there was no connection between a driving under the influence offense and a physician's competence to practice medicine).

187 Wendte v. State, Bd. of Real Estate Appraisers, 70 P.3d 1089, 1089 (Alaska 2003). 
Appraisers suspended Wendte's real estate appraiser's license under state statute section 08.87.210(2), which permits the Board to discipline an appraiser that has "been convicted of a crime involving moral turpitude." 188 Wendte appealed the Board's decision, arguing that there must be "a nexus between a crime of moral turpitude" and the nature of his job before his license could be revoked. ${ }^{189}$ Because the theft was not "directly related to his appraisal activities," Wendte maintained that his license should not have been suspended. ${ }^{190}$ The issue reached the Supreme Court of Alaska, which found that "a licensing board need not establish that there is a nexus between a crime involving moral turpitude and one's ability to carry out the professional duties to issuing sanctions." "Th1 The court reasoned that because "a crime involving moral turpitude necessarily bears on a real estate appraiser's trustworthiness," suspending Wendte's license as a result of his crime was justifiable. ${ }^{192}$

Various state laws require employers to conduct criminal background checks on applicants for certain job positions. ${ }^{193}$ In 2007, the Ohio legislature enacted statute section 3319.391, which requires school districts to perform background checks on current or future school employees. ${ }^{194}$ If the background check reveals certain convictions (including murder, adulteration of food, and cultivation of marijuana), the school district is required to terminate the employee or decline to hire the job applicant. ${ }^{195}$ The statute, however, does not take into account how long ago the conviction occurred. ${ }^{196}$ In Waldon v. Cincinnati Public Schools, this statute was the subject of a disparate impact claim. ${ }^{197}$ In that case, Gregory Waldon and Eartha Britton, two Cincinnati public school employees, were

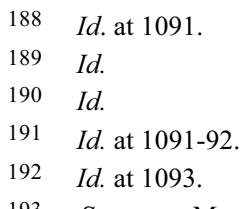

193 See, e.g., MD. CODE ANN., FAM. LAW. § 5-561(b)(1)-(11) (West 2012) (requiring criminal background check of employees working at a child care center, juvenile detention, public or private school, foster care family home, recreation center operated by the state, a day or residential camp, or a home health agency or community-based health services for minors); 24 PA. STAT. ANN. § 1-111 (West 2012) (requiring criminal background checks of all prospective and current employees of public and private schools and vocation and technical schools); FLA. STAT. ANN. $§ 489.518$ (West 2004) (requiring criminal background check of applicants for employment as a burglar alarm system agent).

194 OHIo Rev. Code ANN. § 3319.391 (West 2010); J. Corey Asay \& Ryan W. Green, Another Background Check Pitfall? Following a State Law Mandate to Conduct Background Checks May Not be a Defense in Title VII Disparate Impact Cases, LEXOLOGY (July 8, 2013), http://www.lexology.com/ library/detail.aspx?g=d3afd92a-c57b-4a4f-8d46-3d76c637472e.

195 OHIo REV. CodE ANN. § 3319.391 (West 2010); Asay \& Green, supra note 194.

196 Asay \& Green, supra note 194.

197 Waldon v. Cincinnati Pub. Schs., No. 1:12-CV-00677, 2013 WL 1755664, at *1 (S.D. Ohio Apr. 24, 2013). 
terminated pursuant to the new Ohio law, based on crimes they had committed decades before. ${ }^{198}$ Waldon was found guilty of felonious assault in 1977 and Britton was convicted of acting as an intermediary in the purchase and sale of $\$ 5.00$ worth of marijuana in $1983 .{ }^{199}$ The employees had both worked for the school district for a number of years without disciplinary issues. ${ }^{200}$ Despite this, the school board terminated Waldon and Britton along with eight other employees because of their criminal histories. ${ }^{201}$ Of the ten employees who were terminated, nine were AfricanAmerican. ${ }^{202}$ Waldon and Britton filed suit against the school district alleging racial discrimination in violation of federal and state law, and arguing that their termination was based on a state law that caused a racial disparate impact. ${ }^{203}$ The school district filed a motion to dismiss arguing that it was simply following Ohio's law when it terminated Waldon and Britton, ${ }^{204}$ and that complying with the Ohio law was a business necessity. $^{205}$

In deciding the school district's motion to dismiss, the court examined the purpose and public policy implications of the Ohio criminal background law. ${ }^{206}$ The court considered the law, as applied to serious, recent crimes, and addressed the level of risk in hiring the employees due to the employees' proximity to children. ${ }^{207}$ The court also considered the law as applied to the plaintiffs in this case, noting that the law "operated to bar employment when their offenses were remote in time." 208 The court reasoned:

These Plaintiffs posed no obvious risk due to their past convictions, but rather were valuable employees, who merited a second chance. "To deny job opportunities to these individuals because of some conduct which may be remote in time or does not significantly bear upon the particular job requirements is an unnecessarily harsh and unjust burden., 209

In essence, the court determined that the Ohio law did not comport

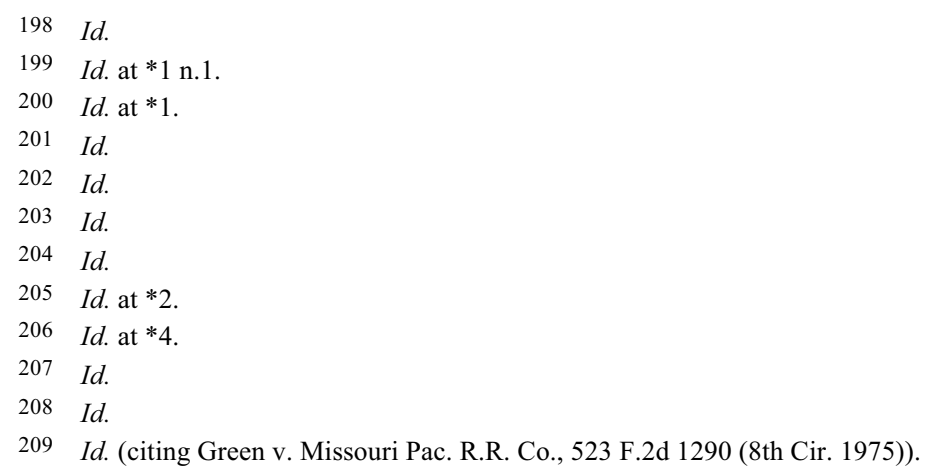


with the Green factors and unjustifiably barred certain ex-offenders from employment. $^{210}$

A discrepancy exists between the EEOC's prohibition of blanket criminal background check policies and states' blanket occupational license restrictions based on an individual's criminal background. ${ }^{211}$ How can the EEOC prohibit an employer from discriminating against an applicant based on a criminal record, yet a state may blatantly do so? ${ }^{212}$ At least one licensee has filed suit against a city arguing that the denial of occupational licenses on the basis of a criminal record is a violation of equal protection and due process. ${ }^{213}$ In Darks v. City of Cincinnati, Harry Darks applied for a license to operate a dance hall. ${ }^{214}$ The city denied Darks' license application because he had been convicted of a felony for receiving and concealing stolen goods. ${ }^{215}$ Darks filed a suit against the city, but the court rejected his equal protection and due process arguments, noting that states have a "particularly strong interest or need to protect the public from those with criminal propensities." $" 216$

A state's classification of felons as a group excluded from obtaining certain occupational license is subject to rational review. ${ }^{217}$ A classification will not violate equal protection or due process if "any set of facts reasonably may be conceived to justify it." ${ }^{, 18}$ But where must the line be drawn? It seems that rational review gives states wide latitude to discriminate against ex-offenders. ${ }^{219}$ In essence, states themselves are

210 The three Green factors are: (1) The nature and gravity of the offense or conduct; (2) The time that has passed since the offense, conduct and/or competition of the sentence; and (3) The nature of the job held or sought. See EEOC Guidance, supra note 16.

211 Id.; Lahny R. Silva, In Search of a Second Chance: Channeling BMW v. Gore and Reconsidering Occupational Licensing Restrictions, 61 U. KAN. L. REV. 495, 506-07 (2012) ("These [occupational license] restrictions have assumed the form of blanket prohibitions based on an individual's status as a convicted felon.").

212 See, e.g., Corro v. Moss, 184 Misc. 1050, 1051 (N.Y. Sup. Ct. 1945) (state revoking barber's license for misdemeanor conviction of possessing policy slips); Nguyen v. Bureau of Prof'1 \& Occupational Affairs, State Bd. of Cosmetology, 53 A.3d 100, 101 (Pa. Commw. Ct. 2012) (state revoking nail technician's license for a felony conviction of entering into a marriage for the purpose of evading provisions of immigration law); Schrer v. Dep't of Bus. \& Prof'l, etc., 919 So. 2d 662, 663 (Fla. 5th Dist. Ct. App. 2006) (state denying general contractor's license for a conviction of possession and conspiracy to possess marijuana with intent to distribute).

213 Darks v. City of Cincinnati, 745 F.2d 1040, 1041 (6th Cir. 1984); see also Silva, supra note 211 , at 495 .

214 Darks, 745 F.2d at 1041.

215 Silva, supra note 211, at 495.

216 Darks, 745 F.3d at 1043.

217 Id. at 1042; Baer v. City of Wauwatosa, 716 F.2d 1117, 1123 (7th Cir. 1983); Schanuel v. Anderson, 708 F.2d 316, 319 (7th Cir. 1983).

218 United States v. Neary, 552 F.2d 1184, 1189 (7th Cir. 1977).

219 See generally supra note 212. 
contributing to recidivism rates and unemployment figures by excluding exoffenders from certain professions. In order to combat the disparate impact and issues associated with denying employment to ex-offenders, states should be held to the same standards as private employers when denying occupational licenses to ex-offenders.

\section{B. Employer Prerogative Must Take a Back Seat}

With much talk about how criminal background checks affect exoffenders' employment prospects, ${ }^{220}$ little attention has been paid to the employer's prerogative to choose whom to hire. An employer has the right to manage its business as it pleases. ${ }^{221}$ Management prerogatives include the right to hire and fire, maintain order and efficiency within the workplace, and control assignments and work environment. ${ }^{222}$ However, there are federal and state regulations that restrict employers from exercising their absolute prerogative in the workplace. ${ }^{223}$ For the most part, employment laws that restrict employer prerogatives tend to be "proscriptive rather than prescriptive. $" 224$ In other words, these laws prohibit employers from doing certain things such as discriminating on the basis of membership in a protected class, rather than requiring employers to take certain actions such as providing paid leave to their employees. ${ }^{225}$ So is prohibiting an employer

220 See, e.g., Mark Montoya, I Got Arrested for a DUI, How Will It Affect Job Opportunities, EXAMINER (Dec. 9, 2013), http:/www.examiner.com/article/i-got-arrested-for-dui-how-will-it-affectjob-opportunities; Stan Alcorn, “Check Yes or No”: The Hurdles of Job Hunting With a Criminal Past, NPR (Jan. 31, 2013, 4:11 PM), http://www.npr.org/2013/01/31/170766202/-check-yes-or-no-thehurdles-of-employment-with-criminal-past; Kai Wright, Boxed In: How a Criminal Record Keeps You Unemployed for Life, THE NATION (Nov. 5, 2013), http://www.thenation.com/article/177017/boxedhow-criminal-record-keeps-you-unemployed-life\#; Ross, supra note 15; Alcorn, supra note 18.

221 Francis C. Amendola et al., Rights of Employers and Employees, 51 C.J.S. LABOR RELATIONS $\S 7$ (2013).

222 Id.

223 See, e.g., 42 U.S.C. $§ 2000 \mathrm{e}-2(\mathrm{a})(1)$ (1964) (prohibiting an employer from discharging or refusing to hire an individual because of such individual's race, color, religion, sex, or national origin); 29 U.S.C. § 623(a)(1) (1967) (prohibiting an employer from discharging or refusing to hire an individual because of an individual's age); 42 U.S.C. § 12112(a) (1990) (prohibiting an employer from discriminating against a qualified individual on the basis of disability in regard to job application, procedures, hiring, advancement, discharge, compensation, training, and privileges of employment); 29 U.S.C. § 158(a)(2) (1935) (prohibiting an employer from dominating or interfering with the formation or administration of any labor organization); COLO. REV. STAT. \$24-34-402.5 (2007) (prohibiting an employer from terminating the employment of any employee due to the employee's engaging in unlawful activity off the premises of the employer during non-working hours); N.Y. HUMAN RIGHTS LAW § 296(1)(a) (McKinney 2010) (prohibiting an employer from discharging or refusing to hire an individual because of their sexual orientation); 43 PA. CONS. STAT. ANN. $\$ 109$ (West 1913) (requiring toilets, wash-rooms, and retiring rooms be provided in every establishment where women are employed).

224 Ellinor P. Schroeder, Regulating the Workplace Through Mandated Personnel Policies, 48

U. KAN. L. REV. 593, 594 (2000).

225 Id. 
from using an individual's criminal background as a determinative factor in the hiring process a permissible restriction of employer prerogative? In our at-will employment system, employers may take action against an employee, without incurring liability, so long as the action is not illegal or does not violate public policy. ${ }^{226}$ It has been argued that because the use of blanket criminal background policies has a disparate impact on the employment opportunities of blacks and Hispanics, ${ }^{227}$ it is unlawful for employers to consider criminal backgrounds during the hiring process. ${ }^{228}$ But perhaps a stronger argument ${ }^{229}$ is - an employer may be subject to liability for using background checks as a determinative factor in the hiring and employment process because the use of criminal records in employment decisions violates public policy. ${ }^{230}$

At least one jurisdiction has recognized the possibility that an employer's improper use of criminal records in employment decisions violates public policy norms. ${ }^{231}$ In Smith v. USG Corporation, Christeen Smith applied for employment with USG. ${ }^{232}$ On her job application, Smith disclosed she had a criminal record. ${ }^{233}$ Despite possessing a criminal background, USG offered Smith a job. ${ }^{234}$ However, USG terminated Smith shortly after commencing employment claiming it "erred in hiring her because she had a criminal record." ${ }^{, 235}$ Smith filed suit against USG alleging her termination was in violation of Pennsylvania law, ${ }^{236}$ which restricts the consideration an employer may give to the criminal history of an applicant. ${ }^{237}$ USG claimed that the law applies only to hiring and not to decisions to terminate an already-hired employee. ${ }^{238}$ The trial court agreed

226 BORDEAU \& VAN ARSDALE, supra note 26.

227 EEOC Guidance, supra note 16.

228 Id.

229 Considering that the EEOC has been unsuccessful in its latest disparate impact lawsuit against an employer using criminal background check policies in its employment decisions, a more successful alternative may be to argue against the use of criminal backgrounds from a public policy standpoint. See EEOC v. Freeman, No. RWT 09cv2573, 2013 WL 4464553, at *11 (D. Md. Aug. 9, 2013) (describing the EEOC's attempt to establish that an employer's hiring policy involving criminal background checks resulted in a disparate impact as "laughable").

230 See Smith v. USG Corp., No. 101 MDA 2013 (Pa. Super. Ct. Sept. 27, 2013), available at http://www.pacourts.us/assets/opinions/Superior/out/j-s49018-13m\%20-\%201015664281745357. pdf\#search=\%22USG\%20Corp. $\% 22$.

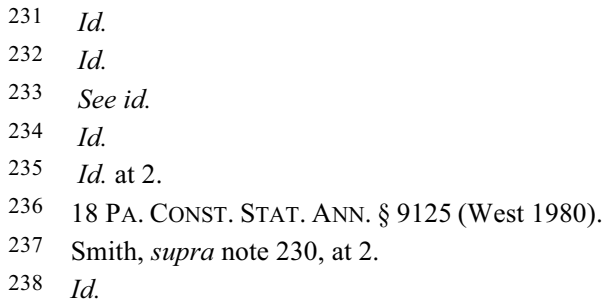


with USG and found in its favor. ${ }^{239}$ On appeal, however, the Superior Court of Pennsylvania reversed the trial court's decision, finding that the Pennsylvania law applied in this case because USG was informed of Smith's criminal record before it hired her. ${ }^{240}$ The court further concluded that there was "possibly a public policy issue because USG's termination of Smith, while after her hiring, may have been a decision concerning Smith's criminal background made within or during the hiring process. ${ }^{241}$

The use of criminal records in employment decisions violates public policy because it stigmatizes ex-offenders as individuals unworthy of trustworthiness. ${ }^{242}$ With such a heavy stigma, ex-offenders will hardly, if ever, successfully re-integrate into our society, thus leading them to return to a life of crime. ${ }^{243}$ As the court in Graffice reasoned, if "an employer can never hire a person with a criminal record ... it would offend our civilized concept that society must make a reasonable effort to rehabilitate those who have erred so they can assimilate into the community." 244 Thus, in a sense, as members of the community, employers have, or should have, a duty to help facilitate the rehabilitation and re-integration of ex-offenders into our communities by providing them with an opportunity to work, despite their mischievous pasts. To achieve this, employers' prerogative must take a back seat.

\section{This Isn't the First Time Employers Shout “That's My Prerogative!"}

When Title VII was first introduced into Congress, employers' main concern was to what extent the new law would affect their prerogative. ${ }^{245}$ Opponents of Title VII argued:

If Title VII is enacted, the President of the United States . . would be granted the power to seriously impair the following civil rights of those who fall within the scope of the various titles of this bill: . . . the right of employers "to hire or discharge any individual" and to determine "his compensation, terms, conditions, or privileges of

239 Id.

$240 I d$. at 5.

241 Id. at 7-8.

242 See Lorelei Laird, Ex-offenders Face Tens of Thousands of Legal Restrictions, Bias and Limits on Their Rights, ABA J. (June 1, 2013, 4:00 AM), http://www.abajournal.com/magazine/article/ ex-offenders_face_tens_of_thousands_of_legal_restrictions/; Martin Ricard, Societal, Internal Changes Can Help Ex-offenders Find Forgiveness, Advocates Say, WASH. Post (Sept. 6, 2009), http://www. washingtonpost.com/wp-dyn/content/article/2009/09/05/AR2009090501018.html.

243 See id.

244 Ponticas v. K.M.S. Inv., 331 N.W.2d 907, 913 (Minn. 1983).

245 Chad Derum \& Karen Engle, The Rise of Personal Animosity Presumption in Title VII and the Return to "No Cause" Employment, 81 TEX. L. REV. 1177, 1212 (2003). 
employment."246

Opponents of Title VII further argued that "the effects of Title VII would be far reaching, encroaching on employer prerogative and employment at will." 247 However, proponents of Title VII noted that the purpose of the federal legislation was to ensure that employment was granted on the "basis of merit, not race." ${ }^{248}$ And despite employers' strong concerns about the loss of "employer autonomy," "249 Congress enacted Title VII. $^{250}$

The same arguments that were made in 1964 against the passage of Title VII ${ }^{251}$ are being made now against the enforcement of the EEOC's Guidance. $^{252}$ Texas recently filed a lawsuit seeking declaratory and injunctive relief "against the EEOC and its recently promulgated 'enforcement guidance.",253 Texas argued that the EEOC's Guidance "purports to limit the prerogative of employers ... to exclude convicted felons from employment." ${ }^{, 54}$ But if the "employer's prerogative" argument failed to prevent Title VII from being enacted, the same argument must fail against preventing the enforcement of the EEOC's Guidance. In this case, as similarly was the case with Title VII, the Guidance purports to ensure exoffenders obtain employment based on their qualifications and suitability for the job and not based on their criminal background. ${ }^{255}$ Thus, because the Guidance attempts to facilitate the obtainment of employment based on merit, rather than on an employee's criminal background, the employer's prerogative argument should fail as it did when it was argued in opposition to the passing of Title VII. ${ }^{256}$

\section{Proposed Solutions}

Employment may prevent the rate at which ex-offenders re-offend. ${ }^{257}$ However, given the substantial employment barriers ex-offenders face, it is difficult for them to acquire steady, legal employment. ${ }^{258}$ To prevent an

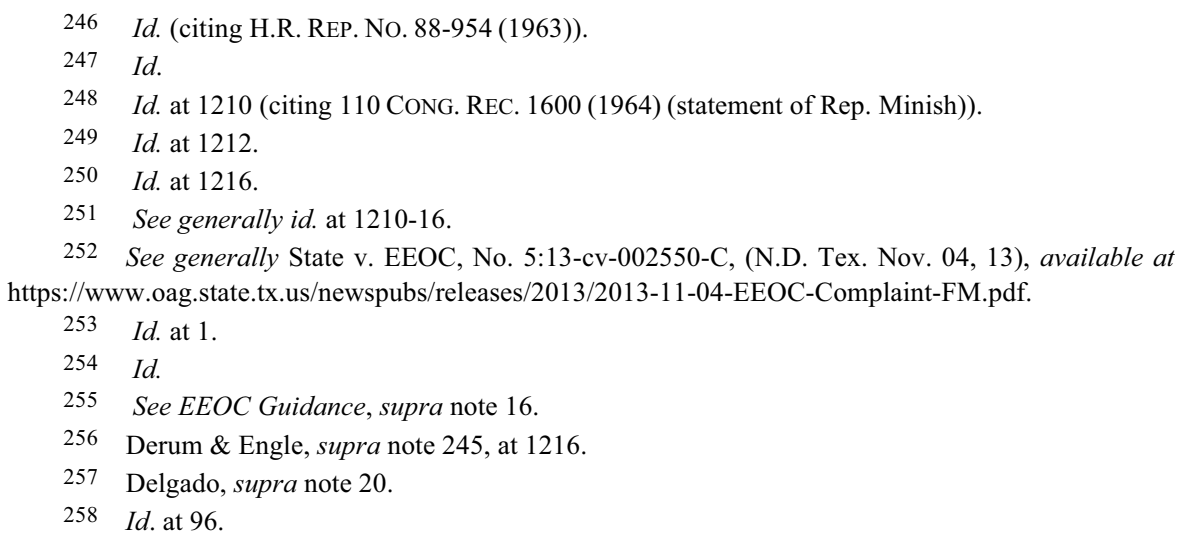


increase in rates of recidivism (and consequently higher crime rates), and to comply with the EEOC's Guidance, employers should consider hiring exoffenders. ${ }^{259}$ There are four proposed ways of reaching this goal:

(1) The criminal justice system should assist ex-offenders through skill building while in prison and help them gain employment upon release; (2) employers should be given incentives to hire ex-offenders; (3) clear statutory guidelines should be established for employers; and (4) crime prevention efforts [that would] reduce opportunities for criminal behavior should be given priority. ${ }^{260}$

Reducing the rate of recidivism, and thus the rate of crime, is imperative to the success of our communities. ${ }^{261}$ The costs of recidivism to society are great: "public safety risks, a weakening of family and community ties, public health risks, and rapidly rising criminal justice costs." ${ }^{262}$ Maintaining all the state prisons in our country alone costs an estimated $\$ 69$ billion a year. ${ }^{263}$

1. Gaining Skills While in Prison May Result in Easier Job Placement for Ex-offenders

Aside from a concern of being held liable for negligent hiring, an employer's concern in hiring ex-offenders is their lack of skills. ${ }^{264}$ In a survey, in which employers were asked to identify factors that would prompt them to hire ex-offenders, more cited education and training (39\%) than any other factor. ${ }^{265}$ An available solution to the lack of skills exoffenders possess is the establishment of in-prison programming or reentry programs where inmates can receive academic and vocational education. ${ }^{266}$ However, a downfall of these reentry programs is the low program participation rates. ${ }^{267}$ Despite a number of incentives, such as good time credits, correctional programming participation continues to decline. ${ }^{268}$ And even when inmates do participate, they tend to abandon and fail to complete the program, particularly when attendance is voluntary. ${ }^{269}$ One possible

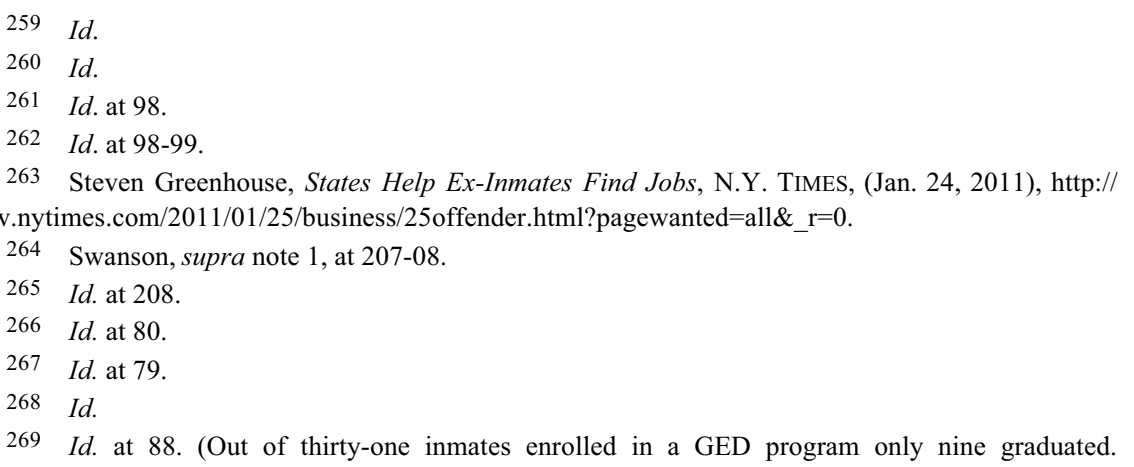


solution to low enrollment and completion rates of reentry programs is to offer inmates incentives they cannot refuse. For example, inmates could receive lower sentences upon successful completion of an in-prison reentry program. ${ }^{270}$

In-prison educational programs will not only aid ex-offenders in obtaining employment, but they can also decrease the rate of recidivism. ${ }^{271}$ Recently, a Maryland state prison official reported that "the percentage of ex-offenders likely to return to prison within three years of release had drastically fallen . . . since 2000." ${ }^{, 72}$ The decrease in recidivism numbers is credited to Maryland's improved educational and job skill in-prison training programs. ${ }^{273}$

A well-run, in-prison reentry program is another key to the success of an inmate's reentry into the community after release from prison. ${ }^{274}$ A study of a reentry program in a medium-security facility located in Massachusetts revealed that an unorganized reentry program might lead to low inmate participation and completion numbers. ${ }^{275}$ At this facility, programs are frequently cancelled or are not run as scheduled. ${ }^{276}$ As a result of the inconsistent operation of the facility's reentry program, a majority of enrolled inmates did not complete the program. ${ }^{277}$

In an effort to alleviate these problems, state governments should allocate a portion of their correctional facilities budgets to funding community-based reentry programs, which would be less expensive and more effective than incarceration or prison-based treatments. ${ }^{278}$ In 2008 , Congress passed the Second Chance Act, which "authorizes federal grants

Similarly, only twenty-seven out of seventy-one inmates enrolled in a culinary arts program completed the program and received a certificate.).

270 This of course should be an option only after taking into account the gravity of the crime, whether the defendant is a first time offender, and other relevant significant and motivating factors.

271 Justin George, Ex-offenders Less Likely to Return to Prison, Maryland Officials Say, BALTIMORE SUN (Sept. 30, 2013), http://articles.baltimoresun.com/2013-09-30/news/bs-md-recidivism20130930_1_recidivism-prison-sentences-ex-offenders.

272 Id. ("The rate at which ex-inmates returned to prison or [were] put on probation for new crimes within three years of release stood at 40.5 percent in 2012, an almost 3 percent drop from the previous year and almost 11 percent lower than in 2000, when the state's recidivism rate stood at 51.4 percent.").

273 Id.

274 See Swanson, supra note 1 , at 80.

275 Id. at 82.

276 Id.

277 Id. at $88-90$. (29\% of inmates successfully completed a GED program; $19 \%$ of inmates successfully completed a heating, ventilation, and air conditioning program; and 38\% successfully completed a culinary arts program).

278 Reentry Matters: Strategies and Successes of Second Chance Act Guarantees Across the United States, JUSTICE CENTER 1, 1 (Nov. 2013), http://csgjusticecenter.org/wp-content/uploads/2013/ 11/ReentryMatters.pdf [hereinafter Reentry Matters]. 
that support reentry programs for adults and juveniles." ${ }^{279}$ Close to 600 federal grants have been awarded to government agencies and non-profit organizations across the country. ${ }^{280}$ The agencies and organizations receiving funding through this federal grant have been successful at aiding ex-offenders gain employment and avoid re-incarceration. ${ }^{281}$ The Harlem Parole Reentry Court in New York is an example of one of the successful programs funded by the Second Chance Act. ${ }^{282}$ The court serves men and women who are assessed to have a medium to high risk of reoffending. ${ }^{283}$ The Reentry Court emphasizes job readiness and employment placement to promote self-sufficiency and accountability. ${ }^{284}$ About one-third of the program's participants found gainful employment within twelve months of being released in comparison to only a quarter of the group of similar individuals who were on parole but did not participate in a reentry court. ${ }^{285}$ Twelve months after release, the re-incarceration rate of ex-offenders was $14.7 \%$ for program participants compared to $19.3 \%$ for non-participants. ${ }^{286}$ These figures indicate that community-based programs are successful in aiding ex-offenders obtain employment after release and avoid reincarceration. ${ }^{287}$ Thus, states should aspire to emulate a program similar to the one funded by the Second Chance Act, as it would increase employment rates amongst ex-offenders, reduce recidivism rates, and decrease state correctional facility expenditures. ${ }^{288}$

\section{Incentivizing Employers to Hire Ex-offenders}

Employers can more easily comply with the EEOC's Guidance and avoid negligent hiring liability if states pass laws limiting liability of employers who hire applicants with criminal backgrounds. Most recently, Texas passed a law preventing a cause of action from being brought against an employer for negligent hiring "based on evidence that the employee was convicted of an offense." ${ }^{289}$ This law, of course, comes with its limitations: the employer may still be liable for negligently hiring an employee if the employer "knew or should have known of the conviction" and "the

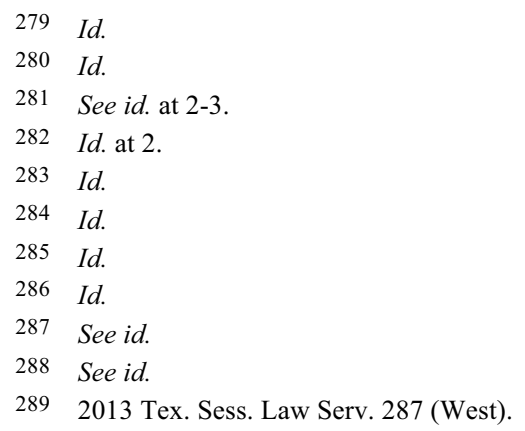


employee was convicted of an offense that was committed while performing duties substantially similar to those to be reasonably expected to be performed in the employment." 290

Another possible solution is for states to provide tax credits to employers who hire ex-offenders. On August 3, 2013, Illinois Governor Pat Quinn passed a law that would make it easier for ex-offenders to find jobs. ${ }^{291}$ The law allows employers to receive a tax credit of up to $\$ 1,500$ for each "qualified ex-offender" it hires. ${ }^{292}$ However, the law is not without limits. The statute bars sex offenders from being considered "qualified exoffenders" for purposes of this law. ${ }^{293}$

The federal government also offers tax credits to employers who hire ex-offenders. ${ }^{294}$ Employers who hire ex-offenders can reduce their taxes by up to $40 \%$ through the Work Opportunity Tax Credit. ${ }^{295}$ However, not many employers are aware of the Work Opportunity Tax Credit. ${ }^{296}$ In a survey of 113 employers, only $35 \%$ of employers were aware of the federal tax credit's existence. ${ }^{297}$ In addition to lack of awareness, employers are not highly incentivized by the credit; ${ }^{298}$ only $16 \%$ of employers surveyed would consider hiring an ex-offender because of the eligible tax break. ${ }^{299}$ Thus, not only should more employers be informed about the Work Opportunity Tax Credit, but an increase in the available tax credit should also be contemplated. ${ }^{300}$ States should also seek to provide employers with tax breaks upon hiring an ex-offender. ${ }^{301}$

The U.S. Department of Labor also provides an incentive for

290 Id.

291 New Illinois Laws Increase Tax Credits for Hiring Ex-Offenders, Give Them a Second Chance-Illinois-Background Checks, CCH ACCOMMODATING DISABILITIES DECISIONS (Wolters Kluwer), Aug. 7, 2013, available at 2013 WL 3991387 [hereinafter Illinois Second Chance Law].

2922013 Ill. Legis. Serv. 98-165, § 216(a) (West).

293 Id. at $\$ 216(\mathrm{c})(1)$.

294 Swanson, supra note 1, at 207.

295 Id.

296 Id. at 208.

297 Id.

298 Perhaps employers feel that the financial incentives do not outweigh the risks associated with hiring ex-offenders.

299 Swanson, supra note 1, at 208.

300 Currently, the maximum tax credit for hiring an ex-offender is $\$ 2,400$. WOTC Tax Credit Amounts, U.S. DEPARTMENT OF LAB. (Apr. 8, 2010), http://www.doleta.gov/business/incentives/opptax/ benefits.cfm.

301 Some states already provide state tax credits to employers who employ ex-offenders. Iowa, for example, provides up to a $\$ 20,000$ deduction per ex-felon. Income Tax Benefit for Iowa Employers Who Hire Ex-offenders, IOWA DEP'T REVENUE, https://tax.iowa.gov/income-tax-benefit-iowaemployers-who-hire-ex-offenders (last visited Feb. 7, 2015); see also Illinois Second Chance Law, supra note 291 (increasing income tax credit to $\$ 1500$ for employers who hire ex-offenders). 
employers to hire ex-offenders. ${ }^{302}$ The Department's Federal Bonding Program provides a government insured bond for up to $100 \%$ for theft for the first six months of employment of ex-offenders. ${ }^{303}$ The program is offered at no cost to the employer and has a successful rate of deterring employee thefts; of the 42,000 bonds issued nationally, only one percent of bond holders have filed claims. ${ }^{304}$

Recently, Ohio and North Carolina have implemented "Certificate of Qualification for Employment" programs. ${ }^{305}$ These programs allow an exoffender to apply for a certificate, which establishes that the ex-offender has been rehabilitated. ${ }^{306}$ The certificate may also be helpful to ex-offenders who are automatically barred from certain occupational licenses on the basis of a criminal background. ${ }^{307}$ Employers who hire ex-offenders who possess this certificate are insulated from negligent hiring claims. ${ }^{308}$

\section{Employers Must Be Provided with Clear Statutory Guidelines}

The most probable effective solution to the criminal background check policy problem is to do away with criminal background inquiries all together. Several cities have joined the "Ban the Box" movement. "B09 "Ban the Box" consists of excluding the criminal history question from job applications. ${ }^{310}$ While the "Ban the Box" movement is a step in the right direction, a job applicant's criminal history may still come to light during the interview phase. ${ }^{311}$ Regardless, the "Ban the Box" movement aids exoffenders with obtaining a job interview, despite their criminal background, and affords them an opportunity to explain themselves and their past

302 See generally, Program Background, FED. BONDING PROGRAM, http://www.bonds4jobs.com/ program-background.html (last visited Feb. 9, 2015).

303 Id.

304 See id.

305 Ohio Department of Rehabilitation and Correction Certificate of Qualification for Employment, OHIO DEPARTMENT OF REHABILITATION AND CORRECTION, http://www.drc.ohio.gov/web/ cqe.htm (last visited Feb. 8, 2014); Alliance Updates, N.C. JUST. CENTER, http://www.ncjustice.org/ ?q=second-chance-alliance/alliance-updates (last visited Feb. 8, 2014).

306 Id.

307 See id.

$308 \quad I d$.

309 Swanson, supra note 1, at 206. Cities that are part of the "Ban the Box" movement include: Boston, Massachusetts; Chicago, Illinois; Minneapolis, Minnesota; Baltimore, Maryland; San Francisco, California; and Norwich, Connecticut. Target Corporation also plans to stop asking prospective employees about their criminal records in initial job applications. See Maxwell Strachan, Target to Drop Criminal Background Questions in Job Applications, HufFington Post (Oct. 29, 2013, 6:24 PM), http://www.huffingtonpost.com/2013/10/29/target-criminal-history-questions_n_4175407.html.

310 Id.

311 Id. 
criminal history during the interview process. ${ }^{312}$

Philadelphia was one of the first cities to pass a "Ban the Box" law. ${ }^{313}$ The law, formerly titled the "Fair Criminal Records Screening Standards Ordinance," has a number of functions; it requires employers to: (1) remove questions about criminal convictions from their job applications; (2) prevents employers from asking about criminal convictions during the initial job interview; (3) protects job applicants from having criminal background checks done prior to the first job interview; and (4) prohibits employers from firing an employee or taking any tangible employment action based on a closed case that did not result in a criminal conviction. ${ }^{314}$ Other cities and states should follow in the footsteps of Philadelphia and pass a progressive law that would help ex-offenders reenter the workplace and avoid recidivism. ${ }^{315}$

Statutory guidelines should not be provided solely to private employers, but should also be provided to state and federal agencies. States have much more leeway in denying job opportunities to ex-offenders through the denial of occupational licenses. ${ }^{316}$ Unfortunately, because felons are not considered a suspect class $^{317}$ and employment is not a fundamental right, ${ }^{318}$ states tend to prevail in an equal protection challenge to occupational licensing restrictions. ${ }^{319}$ The balancing test generally favors

312 Brent Staples, What it Means to 'Ban the Box', N.Y. TIMES (Oct. 20, 2013, 3:01 PM), http:// takingnote.blogs.nytimes.com/2013/10/30/what-it-means-to-ban-the-box/? php=true \&_type=blogs \& $\mathrm{r}=0$.

313 See Ban the Box, Philadelphia COMmission ON HuM. Rel., http://www.phila.gov/ HumanRelations/DiscriminationAndEnforcement/Pages/BanTheBox.aspx (last visited Aug. 30, 2014).

314 Id.

315 Richmond, California is the latest city to pass a "Ban the Box" law. Robin Wilkey, "Ban the Box" Ordinance in California City is Landmark Move for Former Inmates on Job Hunt, HUFFINGTON POST (Aug. 5, 2013, 4:56 PM), http://www.huffingtonpost.com/2013/08/05/ban-the-box-california_n 3708947.html ("While similar legislation has been passed in dozens of municipalities across the country, the Richmond ordinance takes it a step further by not requiring applicants to disclose criminal histories at any point, including during the final rounds of interviews or after they're hired."). But see Delaware Small Business Says No to "Ban the Box", NFIB (Jan. 23, 2014), http://www.nfib.com/article/delawaresmall-business-says-no-to-ban-the-box-64646/ (discussing the National Federation of Independent Business's opposition to Delaware Governor's proposal on passing a "Ban the Box" legislation. "Private small business owners need the flexibility to use their own criteria for hiring employees.").

316 See generally Silva, supra note 211.

317 See 42 U.S.C. $§ 2000 \mathrm{e}-2$ (a) (1991) (omitting felons from list of protected classes); see also Baer v. City of Wauwatosa, 716 F.2d 1117, 1125 (7th Cir. 1983) (“[F]elons are not yet a protected class under the Fourteenth Amendment.").

318 Okla. Educ. Ass'n v. Alcoholic Beverage Laws Enforcement Comm'n, 889 F.2d 929, 932 ("[T]he Supreme Court has never recognized a fundamental right to pursue a particular line of employment.") (citing United Bldg. \& Constr. Trades of Camden Cnty. \& Vicinity v. Mayor and Council of City of Camden, 465 U.S. 208, 219 (1984) ("no fundamental right to government employment under the equal protection clause.")).

319 Silva, supra note 211, at 499. 
the state, with courts finding that a state's interest in safety outweighs an "individual's interest in earning a livelihood." 320 However, a state's legitimate interest in "protect[ing] the public from those with criminal propensities" ${ }^{\prime 21}$ is sometimes not supported by the facts of each case. How is marriage fraud correlated with being a nail technician ${ }^{322}$ or possession of marijuana with being a general contractor $?^{323}$ In reality, these crimes are not related to the nature of the job for which an occupational license may be sought. Yet states may deny occupational licenses to applicants with minor and unrelated convictions. ${ }^{324}$ If private employers are required to abide by the EEOC's Guidance, so should states administering occupational licenses. ${ }^{325}$ In order to eradicate the multiple consequences of using criminal backgrounds to "screen" for potential liability, states should be held to the same standard as private employers. Otherwise, ex-offenders have little chance at obtaining legal employment and reintegrating themselves into our communities. ${ }^{326}$

\section{Preventing Crime Should Be the Top Priority}

Preventing crime would be the best solution to the problem posed by the use of criminal background checks in the employment process. With fewer crimes, fewer individuals would possess criminal records. Hence, fewer individuals would be denied employment based on their criminal history. Crime prevention is the key to achieving this. One way of preventing crime is through the establishment of community organizations that keep at-risk individuals away from situations where they may engage in criminal activity. ${ }^{327}$ DC Central Kitchen is an example of a community

320 Id

321 Darks v. City of Cincinnati, 745 F.2d 1040, 1043 (6th Cir. 1984).

322 Nguyen v. Bureau of Prof'l \& Occupational Affairs, State Bd. of Cosmetology, 53 A.3d 100, 101 (Pa. Commw. Ct. 2012).

323 Schrer v. Dep't of Bus. \& Prof'1, etc., 919 So. 2d 662, 663 (Fla. 5th Dist. Ct. App. 2006).

324 See generally Silva, supra note 211; ALASKA STAT. § 08.87.110(a)(4) (West 2013) (prohibiting a person convicted of a crime involving moral turpitude from holding a real estate appraiser certificate); OHIO REV. CODE ANN. § 4709.13 (B)(1) (West 2011) (refusing to renew or revoking a barber's license if convicted of or pleads guilty to any felonious crime); N.J. STAT. ANN. § 45:1-29(a) (West 2005) (denying a healthcare professional's license for possessing a criminal record).

325 But see EEOC Guidance, supra note 16 ("Title VII also does not preempt federal statutes and regulations that govern eligibility for occupational licenses and registrations.”)

326 See generally SCHLAGER, supra note 20.

327 See, e.g., Community Interventions, NAT'L CRIM. JUST. REFERENCE SERVICE, https://www. ncjrs.gov/html/ojjdp/jjbul9910-1/comm.html (last visited Feb. 15, 2014); What Are Community-Based Crime Prevention Programs?, BuREAu OF Justice Assistance, https://www.bja.gov/evaluation/ program-crime-prevention/cbcp1.htm (last visited Feb. 15, 2014); Crime Prevention Coalition of America, NAT'L CRIM. PREVENTION COUNCIL, https://www.ncpc.org/programs/crime-preventioncoalition-of-america/ (last visited Feb. 15, 2014). 
organization that helps rehabilitate ex-offenders. ${ }^{328}$ DC Central Kitchen enrolls ex-offenders in a "culinary job training program" that serves as a method of employment and an opportunity to obtain job skills. ${ }^{329}$ The organization has had a great success with its program. ${ }^{330}$ Of the seventy-five percent of DC ex-offenders participating in the program, only two percent re-offend. ${ }^{331}$ The program's success has even saved the District of Columbia over two million dollars in prison costs. ${ }^{332}$

Another method of preventing crime is through neighborhood watch programs. ${ }^{333}$ Such programs can be organized around a neighborhood with the help of law enforcement officials. ${ }^{334}$ A study conducted by the National Crime Prevention Council found that nineteen of thirty-six (53\%) neighborhood watch programs studied resulted in positive effects of reducing crime by nine percent or more. ${ }^{335}$ However, since most neighborhood watch programs do not have a formal budget, their effectiveness may suffer due to a lack of funding. ${ }^{336}$ As a remedy, states should consider funding local neighborhood watch programs that are set up according to guidelines established by local law enforcement agencies. ${ }^{337}$ With a well-run neighborhood watch program in place, crime rates may lower, thus decreasing the number of offenders sent to prison, and consequently reducing the amount of tax dollars expended on the criminal justice system. ${ }^{338}$ With these savings, states may be able to fund these local

328 Supporting Ex-Offender Reentry and Fighting Criminal Recidivism, D.C. CENT. KITCHEN, http://www.dccentralkitchen.org/supportingexoffenders/\# (last visited Feb. 15, 2014).

$329 \quad I d$

$330 I d$

331 Id

$332 I d$

333 About Neighborhood Watch, USA ON WATCH, http://www.usaonwatch.org/about/ neighborhoodwatch.aspx? (last visited Feb. 15, 2014) ("Neighborhood Watch is a crime prevention program that stresses education and common sense. It teaches citizens how to help themselves by identifying and reporting suspicious activity in their neighborhoods. In addition, it provides citizens with the opportunity to make their neighborhoods safer and improve the quality of life. Neighborhood Watch groups typically focus on observation and awareness as a means of preventing crime and employ strategies that range from simply promoting social interaction and 'watching out for each other' to active patrols by groups of citizens.").

334 Id.

335 Does Neighborhood Watch Reduce Crime?, NAT'L CRIM. PREVENTION CENTER, http://www. ncpc.org/resources/files/pdf/neighborhood-safety/does-neighborhood-watch-reduce-crime.pdf (last visited Feb. 15, 2014).

336 About Neighborhood Watch, supra note 333.

337 See e.g., Shula Neuman, Neighborhood Watch Programs Could Get State Funding Under Proposed Bill, ST. LOUIS PUB. RADIO (Feb. 7, 2014, 3:52 PM), http://news.stlpublicradio.org/post/ neighborhood-watch-programs-could-get-state-funding-under-proposed-bill ("The Missouri legislature is considering a proposal to provide state funds for neighborhood watch programs in high crime areas around the state.").

338 See generally U.S. Prison Population Drops for Third Year as States Adopt New Policy 
neighborhood watch programs. ${ }^{339}$

While the road to eradicating the employment problems ex-offenders face is an arduous one, these remedies are a step in the right direction. With more state legislatures passing "Ban the Box" legislation and laws limiting an employer's liability for negligent hiring claims, ${ }^{340}$ ex-offenders are much closer to erasing the "mark" created by their criminal convictions. There will hopefully soon be a day where ex-offenders are judged by their skills and qualifications and not by their past decisions.

\section{CONCLUSION}

While critics have opposed the EEOC's enforcement of its Guidance, its enforcement is necessary not only to prevent the disparate impact these criminal background policies have on African-Americans and Hispanics, but it is also necessary to prevent an increase in the unemployment rates of ex-offenders and its consequential increase in recidivism. Reducing the number of ex-offenders returning to prison may contribute to lower crime rates and taxpayer expenditures and an increase in employment rates. Despite the employer's prerogative, wholly embraced by the at-will employment system of managing all aspects of its business environment without significant restrictions, there are instances where an employer's prerogative must take a back seat. When an ex-offender is fired from his job for a minor crime he committed almost fifty years ago, an employer's prerogative should no longer matter. ${ }^{341}$ Thus, in order to move forward, we must let go of the past. To guarantee the success of reintegrating exoffenders into our community, we must do just this.

Strategy, PEw STATES (Aug. 8, 2013), http://www.pewstates.org/news-room/press-releases/us-prisonpopulation-drops-for-third-year-as-states-adopt-new-policy-strategies- 85899496150 (discussing that the decrease in prison population is attributed to alternative strategies implemented to reduce recidivism. Such strategies have cut prison costs by nearly $\$ 2$ billion).

339 Alternatively, these neighborhood watch programs may be funded by neighborhood businesses that have an interest in conducting business in a safe, crime free neighborhood. See Shula Neuman, Neighborhood Watch Programs Could Get State Funding Under Proposed Bill, ST. LOUIS PUB. RADIO (Feb. 7, 2014, 3:52 PM), http://news.stlpublicradio.org/post/neighborhood-watch-programscould-get-state-funding-under-proposed-bill ("[One neighborhood watch program in Missouri] ... was funded by area business owners who were fed up with the petty crimes that scared away visitors and discouraged people from buying houses in the neighborhood.").

340 See, e.g., 2013 Tex. Sess. Law Serv. 287 (West); HAW. REV. STAT. § 378-2.5 (West 2013); Philadelphia, PA., CODE $§ 9-3503$ (2013).

341 See Ed Payne, A "Nickle-and-Dime" Crime Almost 50 Years Ago Gets 68-Year Old Employee Fired, CNN (Aug. 30, 2012, 5:46 AM), http://www.cnn.com/2012/08/30/us/iowa-fired-for-adime/ (discussing the story of a 68-year-old man who was fired by Wells Fargo for a petty crime he committed almost 50 years ago. He got caught using a cardboard cutout of a dime to run a laundromat washing machine when he was 19.). 